\title{
Methane dynamics of aquaculture shrimp ponds in two subtropical estuaries, Southeast China: dissolved concentration, net sediment release, and water oxidation
}

Article

Accepted Version

Yang, P., Lai, D., Yang, H., Tong, C., Lebel, L., Huang, J. and $\mathrm{Xu}$, J. (2019) Methane dynamics of aquaculture shrimp ponds in two subtropical estuaries, Southeast China: dissolved concentration, net sediment release, and water oxidation. Journal of Geophysical Research: Biogeosciences, 124 (6). pp. 1430-1445. ISSN 2169-8961 doi:

https://doi.org/10.1029/2018JG004794 Available at https://centaur.reading.ac.uk/84306/

It is advisable to refer to the publisher's version if you intend to cite from the work. See Guidance on citing.

To link to this article DOI: http://dx.doi.org/10.1029/2018JG004794

Publisher: American Geophysical Union

All outputs in CentAUR are protected by Intellectual Property Rights law, including copyright law. Copyright and IPR is retained by the creators or other copyright holders. Terms and conditions for use of this material are defined in the End User Agreement. 


\section{www.reading.ac.uk/centaur}

\section{CentAUR}

Central Archive at the University of Reading

Reading's research outputs online 


\section{Methane dynamics of aquaculture shrimp ponds in two subtropical estuaries, Southeast China: Dissolved concentration, net sediment release,}

\section{and water oxidation}

Ping Yang ${ }^{1,2,3}$, Derrick Y.F. Lai ${ }^{4 *}$, Hong Yang ${ }^{5,6,7}$, Louis Lebel ${ }^{8}$, Chuan Tong ${ }^{1,2,3 * *}$, Jiafang Huang ${ }^{1,2}$, Jin $\mathrm{Xu}^{1,2}$

${ }^{1}$ Key Laboratory of Humid Subtropical Eco-geographical Process of Ministry of Education, Fujian Normal University, Fuzhou 350007, P.R. China,

${ }^{2}$ School of Geographical Sciences, Fujian Normal University, Fuzhou 350007, P.R. China,

${ }^{3}$ Research Centre of Wetlands in Subtropical Region, Fujian Normal University, Fuzhou 350007, P.R. China,

${ }^{4}$ Department of Geography and Resource Management, The Chinese University of Hong Kong, Shatin, New Territories, Hong Kong SAR, China,

${ }^{5}$ Collaborative Innovation Center of Atmospheric Environment and Equipment Technology, Jiangsu Key Laboratory of Atmospheric Environment Monitoring and Pollution Control, School of Environmental Science and Engineering, Nanjing University of Information Science \& Technology, 219 Ningliu Road, Nanjing 210044, China,

${ }^{6}$ College of Environmental Science and Engineering, Fujian Normal University, Fuzhou 350007, China,

${ }^{7}$ Department of Geography and Environmental Science, University of Reading, Whiteknights, Reading, RG6 6AB, UK,

${ }^{8}$ Unit for Social and Environmental Research, Chiang Mai University, Chiang Mai 50200, Thailand

*Correspondence to: Derrick.Y.F. Lai

Telephone: 852-39436528

Fax: 852-26035006

Email: dyflai@cuhk.edu.hk (D.Y.F. Lai)

**Correspondence to: Chuan Tong

Telephone: $086-0591-87445659$

Fax: 086-0591-83465397

Email: tongch@fjnu.edu.cn (C. Tong) 


\begin{abstract}
Aquaculture ponds are important atmospheric $\mathrm{CH}_{4}$ sources with strong temporal variability, yet the variation in $\mathrm{CH}_{4}$ concentrations and other biogeochemical processes (e.g., $\mathrm{CH}_{4}$ production and oxidation) among estuaries and aquaculture stages are poorly understood. In this study, we assessed the $\mathrm{CH}_{4}$ sediment release, oxidation, and dissolved concentrations of aquaculture ponds in two subtropical estuaries in the different growth stages of shrimps. Overall, porewater $\mathrm{CH}_{4}$ concentrations and sediment $\mathrm{CH}_{4}$ release rates from the shrimp ponds varied greatly between different stages and followed the order: middle stage > final stage > initial stage. Water column $\mathrm{CH}_{4}$ concentrations, and overlying water $\mathrm{CH}_{4}$ oxidation rates indicated a growth pattern during the research period. There were also large variations in pond sediment $\mathrm{CH}_{4}$ release rates, and dissolved concentration among estuaries. These variations can be mainly attributed to the interactions of salinity and other abiotic factors (e.g., $\mathrm{pH}$ and substrate availability). Furthermore, lower sediment $\mathrm{CH}_{4}$ release rates, and high shrimp survival rate and yield were observed in Jiulong River Estuary with high water salinity compared to that in Min River Estuary with low water salinity. The results implies that increasing the salinity level of shrimp ponds and improving feed utilization efficiency might be an important strategy to mitigate $\mathrm{CH}_{4}$ emissions and increase shrimp production. The result will also provide scientific data and support for preparation of wetland resources protection, the sustainable development of fishery economy, and $\mathrm{CH}_{4}$ reduction in coastal zone. Our results emphasize the potential importance of the $\mathrm{CH}_{4}$ biogeochemical cycle in aquaculture ponds and its contribution to the global $\mathrm{CH}_{4}$ cycle. In the future work, the need to obtain high-frequency and continuous field measurements over the long term at multiple spatial scales, and to further identify the effect of microbial mechanisms on $\mathrm{CH}_{4}$ biogeochemical cycle in coastal aquaculture ponds to reveal the causalities of spatial and temporal variations.
\end{abstract}




\section{Introduction}

Worldwide concern regarding global climate change and its effects on various environments requires a better understanding of greenhouse gas (GHG) emissions [Tong et al., 2010]. As one of major final products in the process of organic matter degradation [Bridgham et al., 2013], methane $\left(\mathrm{CH}_{4}\right)$ is an important GHGs in the air [IPCC, 2013]. At present, atmospheric $\mathrm{CH}_{4}$ levels have increased threefold since pre-industrial times, reaching $1845 \pm 2 \mathrm{ppb}$ in 2015 [WMO, 2016]. $\mathrm{CH}_{4}$ has accounted for approximately $20 \%$ of global radiative forcing, while the atmospheric concentrations are still growing [WMO, 2016]. Quantifying the potential source of $\mathrm{CH}_{4}$ from various system is an important basis for predicting future $\mathrm{CH}_{4}$ emissions. In terms of atmospheric equilibrium, $\mathrm{CH}_{4}$ is usually over-saturated in inland and coastal aquatic system [Bastviken et al., 2011; Blees et al., 2015; Dutta et al., 2015; Xing et al., 2004; Yang et al., 2015a]; thus, they are considered potentially significant sources of atmospheric $\mathrm{CH}_{4}$ [Bastviken et al., 2011; Musenze et al., 2016; Yang et al., 2011]. Recent estimates suggest that global freshwater $\mathrm{CH}_{4}$ emissions to be $103 \mathrm{Tg} \mathrm{CH}_{4} \mathrm{yr}^{-1}$ [Bastviken et al., 2011], accounting for nearly $25 \%$ of total $\mathrm{CH}_{4}$ emission to the atmosphere [Musenze et al., 2016]. Despite the significance, it is far from clear about various $\mathrm{CH}_{4}$ sources [Martinez-Cruz et al., 2017; Natchimuthu et al., 2016] and $\mathrm{CH}_{4}$ cycling in these aquatic system [Martinez-Cruz et al., 2017]. This is particularly true in the case of $\mathrm{CH}_{4}$ dynamics in aquaculture system.

Similar to other aquatic systems (e.g., lakes, reservoirs and rivers) and wetlands [Bastviken et al., 2008; Lai, 2009; Musenze et al., 2016], $\mathrm{CH}_{4}$ fluxes from aquaculture system is controlled by the production of methanogens, consumption by methanotrophs, and transport via different pathways (e.g., diffusive and bubble), which are in turn, affected by a series of biotic and abiotic variables. In addition to this, a large proportion of produced $\mathrm{CH}_{4}$ is dissolved in porewater in situ high pressure, with the consequence of marked $\mathrm{CH}_{4}$ super-saturation. Dissolved $\mathrm{CH}_{4}$ is released through diffusion from the sediment to the atmosphere, while the residual $\mathrm{CH}_{4}$ undergoes ebullition as gas bubbles [Dutta et al., 2013; Neue et al., 1997]. Furthermore, the surface sediment generally retains a large amount of organic matter from aquatic animal feces and residual feed [Chen et al., 2016; Yang et al., 2017a], which will favor the production of $\mathrm{CH}_{4}$. Therefore, the boundary between water and sediment, i.e., the sediment-water interface (SWI), plays a critical role in producing, transferring, circulating, and storing $\mathrm{CH}_{4}$ in aquaculture ponds [Xiong et al., 2017]. The rapid development of the aquaculture industry has prompted some scholars began to perceive the importance of studying $\mathrm{CH}_{4}$ biogeochemical cycling in aquaculture systems. However, most attempts have been made in $\mathrm{CH}_{4}$ exchange across the water-air interface and the influencing factors [e.g., Chen et al., 2016; Hu et al., 2014; Hu et al., 2016; Yang et al., 2015c;Yang et al., 2018b]. However, detailed studies quantifying $\mathrm{CH}_{4}$ fluxes and their correlative biogeochemical processes (e.g., sediment $\mathrm{CH}_{4}$ release and $\mathrm{CH}_{4}$ oxidation) in aquaculture system have received little attention until now. Carrying out such studies is quite significant for sustainable development and achieving a balance between carbon reduction and aquaculture development.

With the leveling off of capture fisheries production from the 1970s, the aquaculture industry has played an important role to satisfy the growing requirement of aquatic foods, for example fish and shellfish [Hu et al., 2012]. Recent estimates suggest that global aquaculture 
contributes to an increasing proportion of the global fish production from around $10 \%$ in 1985 to $40 \%$ in 2014 [FAO, 2016]. Approximately $90 \%$ of the world's aquaculture production occurs in the Asia-Pacific region [FAO, 2016], and land-based aquaculture ponds are considered the most important part of fish and shrimp production in marine and freshwater environment [Yang et al., 2017a]. As a world leading aquaculture producer, China's total cultivation area and production were up to 58,579 $\mathrm{km}^{2}$ [Verdegem and Bosma, 2009] and 29.4 million metric tons (Mt) in 2015 [Fisheries Department of Agriculture Ministry of China, 2015]. Shrimp pond is one of the major parts of China's aquaculture ponds, with wide distribution around the coastal regions [Yang et al., 2017a]. In these ponds, water is generally influenced by the interactions of seawater and precipitation; hence, there are large variations in salinity between estuaries. Previous studies have indicated that salinity could affect the spatial-temporal variation of $\mathrm{CH}_{4}$ production and emission through its effects on extracellular enzyme activities, carbon mineralization rates and methanogens activities in coastal wetland [e.g., Hu et al., 2017; Poffenbarger et al., 2011; Sun et al., 2013; Vizza et al., 2017; Welti et al., 2017]. Therefore, salinity was considered as an factor influencing $\mathrm{CH}_{4}$ dynamics in the current study. Moreover, previous studies have identified a number of factors controlling the spatial-temporal variation of $\mathrm{CH}_{4}$ biogeochemical processes (e.g., $\mathrm{CH}_{4}$ production, oxidation and emission) from natuarl wetland, rice fields and aquatic eosystems, including temperature [Knox et al., 2016; Olsson et al., 2015; Palma-Silva et al., 2013; Whalen, 2005; Xing et al., 2005], redox level or dissolved oxygen level [Huttunen et al., 2003; Liu et al., 2015], pH [Wang et al., 1993; Hu et al., 2017], salinity [Poffenbarger et al., 2011; Vizza et al., 2017; Welti et al., 2017], water table [Dinsmore et al., 2009; Olsson et al., 2015; Yang et al., 2013b], primary production [Whiting and Chanton, 1993; Xiao et al., 2017], substrate availability [Allen et al., 2007; Venkiteswaran et al., 2013], and competitive electron acceptors [Purdy et al., 2003; Yang et al., 2019]. Furthermore, in an earlier study, Yang et al. [2018] found that $\mathrm{CH}_{4}$ emissions from the aquaculture shrimp ponds into the atmosphere in the subtropical estuaries varied significantly among the different aquaculture stages, with the highest fluxes occurring during the middle stage. As a result of this, there could also be large variations in other $\mathrm{CH}_{4}$ biogeochemical processes from aquaculture ponds between estuaries. Unfortunately, there is little available information that compares $\mathrm{CH}_{4}$ dynamics and its influence factors in aquaculture ponds between estuaries [Yang et al., 2018b].

To increase our understanding of the dynamics of $\mathrm{CH}_{4}$ biogeochemical cycles in shrimp ponds and also improve the accuracy of flux estimates upscaled from local ponds to regional scales, this study made the attempt to research $\mathrm{CH}_{4}$ dynamics (e.g., $\mathrm{CH}_{4}$ dissolved concentrations, sediment $\mathrm{CH}_{4}$ release, and overlying water $\mathrm{CH}_{4}$ oxidation) in aquaculture shrimp ponds during the culture period in two subtropical estuaries in Fujian Province, Southeast China. There are two hypotheses in the current study: (1) the $\mathrm{CH}_{4}$ biogeochemical cycles in the shrimp ponds varied greatly due to the remarkable change in environmental variables (e.g., DO, temperature, $\mathrm{pH}$ and substrate availability) between different culture stages; (2) $\mathrm{CH}_{4}$ dissolved concentrations, sediment $\mathrm{CH}_{4}$ release fluxes, and overlying water $\mathrm{CH} 4$ oxidation rates changed markedly due to the difference in salinity and substrate supply between two estuaries. This study could provide scientific foundation for improving GHG inventories and contribute to the ongoing evaluation by the IPCC Task Force on National Greenhouse Gas Inventories (TFI), particularly the urgent need of estimation of GHG 
emission from various types of flooded land including aquaculture ponds [Yang et al., 2017]. Moreover, this study can provide one major reference for a more accurate prediction, and effective regulation of GHG emission from the aquaculture ponds in the future.

\section{Materials and Methods}

\subsection{Study Site Descriptions}

Our study area was located in the Shanyutan and Humao in the Min River Estuary (MRE) and the Jiulong River Estuary (JRE), southeast China (Figure 1). Min River Estuary has a typically subtropical monsoon climate, warm and wet in summer. The mean annual temperature is around $19.6{ }^{\circ} \mathrm{C}$ and the average annual precipitation is about $1,350 \mathrm{~mm}$ [Tong et al., 2010]. Jiulong River Estuary has a subtropical oceanic climate. The mean annual air temperature is approximately $21.0{ }^{\circ} \mathrm{C}$ and the average annual rainfall is around $1371 \mathrm{~mm}$ [Wang et al., 2013]. The tides are typical semi-diurnal. The mean tide ranges are approximately $4.5 \mathrm{~m}$ and $4.0 \mathrm{~m}$ in these two estuaries. The catchment areas of the MRE and JRE are 60,092 and $14,741 \mathrm{~km}^{2}$, respectively, with mean annual discharges of approximately $58.6 \times 10^{9} \mathrm{~m}^{3}$ and $12.4 \times 10^{9} \mathrm{~m}^{3} \mathrm{y}^{-1}$ [Zhou et al., 2016].

Three shrimp (Litopenaeus vannamei) ponds were randomly selected in each estuary. These ponds had been converted from the tidal marshes in recent years. The shrimp ponds in MRE and JRE were constructed in 2012 and 2006, respectively. Removing marsh vegetation, the shallow pond basins with steep sides and homogenous depth were created. The water in the shrimp ponds is a mix of fresh water drawn locally and sea water pumped from the coast. Aquaculture in most of the shrimp ponds starts in June and ends in November. L. vannamei were fed in both morning (07:00 a.m.) and afternoon (16:00 p.m.) with an artificial diet (Yuehai ${ }^{\mathrm{TM}}$, Guangzhou, China) which contained $42 \%$ of crude protein. The feed amount was estimated according to experience and shrimp response to previous feeding [Casillas-Hernández et al., 2006; Liu et al., 2015] and the feeding rates were controlled at around $10-16,50-55$, and $40-45 \mathrm{~kg} \mathrm{ha}^{-1} \mathrm{~d}^{-1}$ from the initial stage, middle stage, and to the final stage. More details about the shrimp ponds and their management practices can be found in Yang et al. [2017a].

\subsection{Collection and Analysis of Water Samples}

To research shrimp production in different stages (initial, middle, and final stages), field sampling campaigns were performed in June, August, and October 2015. Sampling for the respective estuaries was done separately in each of the three sampling campaigns. Sample collection was performed in estuaries within one day between different estuaries. Three sampling sites were in each pond and water was sampled at three different depths: the surface (approximately $10 \mathrm{~cm}$ below the surface), the middle (between surface and bottom layer), and the bottom (approximately $5 \mathrm{~cm}$ above the surface sediment). On each sampling day, water was collected in morning (08:00 and 11:00), afternoon (14:00), and evening (17:00).

\subsubsection{Dissolved carbon Concentrations in the Water Column}

To measure the dissolved carbon concentrations, water samples were collected using a $5 \mathrm{~L}$ Niskin water sampler, and transferred to $250 \mathrm{~mL}$ polyethylene bottles. To inhibit microbial activity, about $2 \mathrm{~mL}$ of saturated $\mathrm{HgCl}_{2}$ solution was injected into each bottle of water sample [Taipale and Sonninen, 2009; Zhang et al., 2013]. All water samples were subsequently stored in an ice box, transported to the laboratory within $4 \mathrm{~h}$, and analyzed within one week. 
After filtering through a $0.45 \mu \mathrm{m}$ cellulose acetate filter (Biotrans ${ }^{\mathrm{TM}}$ nylon membranes), the samples were analyzed for the levels of dissolved inorganic carbon (DIC), dissolved organic carbon (DOC), and total organic carbon (TOC) and using a SHIMADZU TOC-V $\mathrm{V}_{\mathrm{CPH} / \mathrm{CPN}}$ analyzer (Shimadzu, Kyoto, Japan).

\subsubsection{Physicochemical and Biological Variables of Water Column}

Water temperature and $\mathrm{pH}$ were measured in situ using a portable $\mathrm{pH} / \mathrm{mV} / \mathrm{Temp}$ system (IQ150, IQ Scientific Instruments, USA). Salinity and dissolved oxygen (DO) concentrations at different water depths were determined using a salinity meter (Eutech Instruments-Salt6, USA) and a multi-parameter controller (HORIBA, Japan), respectively. To estimate chlorophyll- $a(\mathrm{Chl}-a)$ concentrations, samples were also collected in $250 \mathrm{~mL}$ polyethylene brown bottles and stored in dark and cold environment during transporting back to laboratory. The Chl- $a$ samples were extracted using $90 \%(\mathrm{~V} / \mathrm{V}$ ) acetone for $24 \mathrm{~h}$ and determined using a UV-visible spectrophotometer (Shimadzu UV-2450, Japan). The Chl- $a$ concentration was calculated based on measurements of absorbance at 665 and $750 \mathrm{~nm}$ [Qu et al., 2007]. In addition, meteorological data including wind speed, air temperature, and atmospheric pressure were measured in situ using a meteorological instrument (NK3500 Kestrel, USA).

\subsubsection{Dissolved $\mathrm{CH}_{4}$ Concentration in Water Column}

A headspace equilibration technique was used to determine dissolved $\mathrm{CH}_{4}$ concentration. Water samples were collected using a $60 \mathrm{~mL}$ pre-weighed serum glass bottle, completely filling them with an air-tight water sampler that limits gas exchange and prevents formation of gas bubbles [Abril et al., 2007; Cotovicz et al., 2016]. To inhibit microbial activity, the bottles were sealed and $0.2 \mathrm{~mL}$ of saturated $\mathrm{HgCl}_{2}$ solution was injected into each water sample [Cotovicz et al., 2016; Dutta et al., 2015]. All water samples were stored in ice cooler, transported back to the laboratory, and analyzed within three days of collection. In the laboratory, a headspace was generated. A total of $30 \mathrm{~mL}$ ultra-pure nitrogen $\left(\mathrm{N}_{2}\right)$ was injected through the top septum of the sampling bottles, a needle was penetrated into the bottom septum, allowing the discharge of an equal volume of water [Wang et al., 2015]. The sampling bottles were then shaken vigorously for $30 \mathrm{~min}$ on a mechanical shaker to equilibrate $\mathrm{CH}_{4}$ between the air and water phase. $\mathrm{CH}_{4}$ concentrations in the headspace were measured using a gas chromatograph (GC-2010, Shimadzu, Kyoto, Japan) equipped with a flame ionization detector (FID). The levels of $\mathrm{CH}_{4}$ in the shrimp pond water samples were estimated based on the solubility coefficients [Wanninkhof, 1992; Yamamoto et al., 1976]. The detailed calculation process of $\mathrm{CH}_{4}$ concentration and saturation followed the description of Wang et al. [2015].

\subsection{Collection and Analysis of Sediment Samples}

On each sampling campaign, twelve intact short sediment cores were sampled in each pond using a surface-operated coring device (Core-60, Austria). The device includes a Plexiglas tube, a core cylinder and a one-way check valve to preserve the integrity of overlying water and sediment [Han et al., 2014]. The intact cores included $15 \mathrm{~cm}$ sediments and $15 \mathrm{~cm}$ overlying water. Sediment samples were immediately sealed and stored vertically in a $4{ }^{\circ} \mathrm{C}$ cooler and transported back to the laboratory within $4 \mathrm{~h}$. In the laboratory, the core of sediment samples was divided into four parts.

\subsubsection{Sediment Physicochemical Parameters}

Sediment $\mathrm{pH}$ was measured using a $\mathrm{pH}$ meter (Orion 868, USA) with a soil-to-water ratio of 
1:2.5, and sediment salinity was determined using a salinity meter (Eutech Instruments-Salt6, USA) with a soil-to-water ratio of 1:5 [Yang et al., 2017a]. Sediment porosity $(\Phi)$ was determined according to the water content of sediment samples which was calculated by the sediment weight difference before and after baking in an oven at $105{ }^{\circ} \mathrm{C}$ for $24 \mathrm{~h}$ [Yang et al., 2017a; Zhang et al., 2013]. Sediment total carbon (TC) was analyzed via a CHN Elemental Analyser (Elementar Vario MAX CN, Germany) on freeze-dried and ground subsamples passing through a $2 \mathrm{~mm}$ sieve [Sun et al., 2013].

\subsection{2. $\mathrm{CH}_{4}$ Concentration and Physicochemical Parameters of Sediment Porewater}

Triplicate sediment samples from each pond were measured for porewater $\mathrm{CH}_{4}$ concentration and physicochemical properties. The collection method of dissolved $\mathrm{CH}_{4}$ concentration in porewater followed the description of Dutta et al. [2015]. Briefly, duplicate $6 \mathrm{~cm}^{3}$ subsamples were collected using 10 plastic syringes with the needle attachment end removed. The subsample plugs from the syringes were immediately extruded into $60 \mathrm{~mL}$ glass serum vials and sealed with blue butyl stoppers and aluminum crimp caps. Approximately $24 \mathrm{~mL}$ of degassed deionized water and $0.5 \mathrm{~mL}$ of saturated $\mathrm{HgCl}_{2}$ solution was then added to serum vials. To inhibit oxidation, porewater samples were processed in nitrogen-filled glove bags [Matos et al., 2016]. To obtain an equilibrium between the slurry and the headspace, the mixtures were shaken on a mechanical shaker [Dutta et al., 2015]. $\mathrm{CH}_{4}$ concentration in the headspace was measured using a gas chromatography (GC-2010, Shimadzu, Kyoto, Japan). The calculation formula of porewater $\mathrm{CH}_{4}$ concentration followed the description of Ding et al. [2005].

Porewater was extracted from the rest of the sediment by centrifugation $(4,000 \mathrm{rpm}, 10 \mathrm{~min}$ Hereaus Omnifuge $2000 \mathrm{RS}$ ). These porewater samples were divided into two groups. A group of porewater samples were filtered through cellulose acetate filters with pore size of $0.45 \mu \mathrm{m}$ (Biotrans ${ }^{\mathrm{TM}}$ nylon membranes) [De Vittor et al., 2012], and the filtrates were analyzed for the concentrations of TOC, DOC, and DIC via a SHIMADZU TOC-VCPH/CPN analyzer. Another group of porewater samples (unfiltered) was used to determine the salinity via a salinity meter (Eutech Instruments-Salt6, USA).

\subsubsection{Incubation and Measurement of Sediment $\mathrm{CH}_{4}$ Release Fluxes}

The final set of three sediment cores were used for incubation and measurement of $\mathrm{CH}_{4}$ relese fluxes across the sediment-water interface (SWI). The incubation device (Figure S1) was structured following Chen et al. [2014a] and Cowan et al. [1996]. With intact structures, approximately 15 -cm-long sediment cores were placed in Plexiglas ${ }^{\circledR}$ incubation chambers (diameter $6 \mathrm{~cm}$, height $30 \mathrm{~cm}$ ) (Figure S1) which were sealed with a Teflon plunger to prevent exposure to the air. The chambers were then completely filled with overlying water up to $15 \mathrm{~cm}$ above the sediment surface. Before the incubation, DO levels of the overlying water in the chambers were adjusted to achieve the level of DO in situ. Finally, the incubation chambers were incubated in a constant temperature oscillation incubator (QHZ-98A, China) device for $9 \mathrm{~h}$. The incubation temperature was consistent with in situ temperature. During the initial time $(0 \mathrm{~h})$ of incubation, $60 \mathrm{~mL}$ of overlying water from the chambers were withdrawn using a $100 \mathrm{~mL}$ airtight polypropylene syringe connected to rubber tubing, and the water was immediately transferred to pre-capped $60 \mathrm{~mL}$ infusion vials. Subsequent samples were collected from the chambers after 3, 6, and $9 \mathrm{~h}$ of the incubation. To inhibit microbial activity, approximately $0.5 \mathrm{~mL}$ of saturated $\mathrm{HgCl}_{2}$ solution was injected to each sample vial. 
Headspace equilibrium technique was used to measure dissolved $\mathrm{CH}_{4}$ concentration in incubated water samples. Water samples were processed and measured following the same procedure as Section 2.2.2. $\mathrm{CH}_{4}$ release fluxes across the SWI were determined according to the concentration variations in overlying water versus time [Wang et al., 2015] (Eq. 1):

$$
F_{\mathrm{S}-\mathrm{w}}=\frac{d \mathrm{c}}{d \mathrm{t}} \times V \times S
$$

where $F_{\mathrm{S}-\mathrm{w}}$ is the flux of $\mathrm{CH}_{4}\left(\mu \mathrm{mol} \mathrm{m} \mathrm{m}^{-2} \mathrm{~h}^{-1}\right)$ at the sediment-water interface; $\frac{d \mathrm{c}}{d \mathrm{t}}$ is variation slope of $\mathrm{CH}_{4}$ concentration over sampling time $\left(\mu \mathrm{mol} \mathrm{L}^{-1} \mathrm{~h}^{-1}\right) ; V$ is the volume of overlying water in the incubation chamber (L); and $S$ is the cross-sectional area of the sediment core $\left(\mathrm{m}^{2}\right)$.

\subsection{Incubation and Measurement of Dissolved $\mathrm{CH}_{4}$ Oxidation in the Overlying Water}

On each aquaculture stage, $\mathrm{CH}_{4}$ oxidation (MOX) was also determined as the decrease of $\mathrm{CH}_{4}$ concentration over time in Plexiglas ${ }^{\circledR}$ incubation chambers [Almeida et al., 2016; Bastviken et al., 2008; Dutta et al., 2015; Figure S1]. The $588.75 \mathrm{~mL}$ incubation chambers ( $n$ $=3$ for each pond) were completely filled with overlying water samples from the $5 \mathrm{~L}$ Niskin bottles using transparent silicon tubes, overflowing each chamber to prevent any air spaces and/or bubbles formation. Finally, the incubation time, conditions, water sampling, and measurement of $\mathrm{CH}_{4}$ oxidation in incubation chambers were performed as described in Section 2.3.3. $\mathrm{CH}_{4}$ oxidation rates $\left(\mu \mathrm{mol} \mathrm{CH}_{4} \mathrm{~m}^{-2} \mathrm{~h}^{-1}\right.$ ) in the incubation chambers were calculated via regressions of concentration and time (Eq. 1; Wang et al., 2015).

\subsection{Statistical Analyses}

Data were transformed to normal distributions when the selected attributes were skewed. Differences in the researched variables among three growth stages of shrimps in each estuary were calculated using one-way Analysis of Variance (ANOVA). For a given estuary and season, the differences in environmental variables, $\mathrm{CH}_{4}$ concentration, and $\mathrm{CH}_{4}$ saturation among the three water depths were also tested using ANOVA. This research tested the statistical differences in studied variables between the two estuaries' shrimp ponds during the study period by repeated measures analysis of variance (RMANOVA). Correlations between biogeochemical dynamics of $\mathrm{CH}_{4}$ and individual environmental variables were tested by Pearson correlation analysis. All statistical analyses were conducted using SPSS version 17.0 (SPSS, Inc., USA). Significance was considered at the level of 0.05. Results are reported as mean \pm 1 SE. Graphs were generated using OriginPro 7.5 (OriginLab Corporation, USA). Conceptual diagrams were plotted using EDraw Max version 7.3 (EdrawSoft, Hong Kong, China).

\section{Results}

\subsection{Dissolved $\mathrm{CH}_{4}$ Concentration in Sediment Porewater and Water Column}

There were large variations in pond sediment porewater $\mathrm{CH}_{4}$ concentration between estuaries and among observation stages (Figure 2). Porewater $\mathrm{CH}_{4}$ concentration from the shrimp pond sediment in the MRE and JRE changed between 13.47 and $95.27 \mu \mathrm{mol} \mathrm{L}^{-1}$, and 2.29 and $29.52 \mu \mathrm{mol} \mathrm{L}{ }^{-1}$, respectively, with the minimum and maximum in the initial and middle stages (Figure 2), respectively. Overall, average porewater $\mathrm{CH}_{4}$ concentration from sediment in the MRE $\left(51.51 \pm 4.41 \mu \mathrm{mol} \mathrm{L}^{-1}\right)$ was significantly larger than that in the JRE $(11.50 \pm 1.56$ 
$\left.\mu \mathrm{mol} \mathrm{L}{ }^{-1}\right)\left(F_{d f=1}=15.717, p<0.01\right.$; Figure 2).

The $\mathrm{CH}_{4}$ concentrations in the pond water column from the MRE and JRE changed between $0.18 \pm 0.01 \mu \mathrm{mol} \mathrm{L}-1$ and $1.20 \pm 0.11 \mu \mathrm{mol} \mathrm{L} \mathrm{L}^{-1}$, and between $0.15 \pm 0.01 \mu \mathrm{mol} \mathrm{L}{ }^{-1}$ and $0.62 \pm 0.03$ $\mu$ mol $\mathrm{L}^{-1}$, respectively (Figure 3), corresponding to the saturation varied between $(226.9 \pm 10.0) \%$ and $(1525.3 \pm 132.8) \%$, and between $(207.7 \pm 9.9) \%$ and $(974.42 \pm 46.37) \%$. $\mathrm{CH}_{4}$ concentrations and saturations from all estuaries showed significant $(p<0.01)$ temporal variation in the order of: final stage $>$ middle stage $>$ initial stage (Figure 3). Average $\mathrm{CH}_{4}$ concentrations and saturations in the pond water column in the MRE were significantly higher $(p<0.05)$ than those in the JRE during the initial and final stages, but only slightly higher $(p>0.05)$ in the middle stage (Figure 3$)$. The mean values of $\mathrm{CH}_{4}$ concentration and saturation grew gradually from the surface to bottom waters, but in most cases the differences were insignificant $(p>0.05)$ (Figure 3$)$.

\section{2. $\mathrm{CH}_{4}$ Release Fluxes Across the Sediemnt-Water Interface}

The dynamics of sediment $\mathrm{CH}_{4}$ release fluxes from the shrimp ponds in the MRE and JRE are shown in Figure 4a. The two estuaries showed similar temporal patterns, with minimum and maximum release fluxes occurring at the initial and middle stages, respectively (Figure 4a). The $\mathrm{CH}_{4}$ release fluxes over the study period ranged from between 5.26 to $168.81 \mu \mathrm{mol} \mathrm{m} \mathrm{m}^{-2}$ $\mathrm{h}^{-1}$, and from 2.93 to $56.74 \mu \mathrm{mol} \mathrm{m} \mathrm{m}^{-2} \mathrm{~h}^{-1}$, respectively. Overall, the mean $\mathrm{CH}_{4}$ release fluxes from the shrimp ponds in the MRE amounted to $84.52 \pm 11.58 \mu \mathrm{mol} \mathrm{m}^{-2} \mathrm{~h}^{-1}$, which was higher than that in the JRE, at $11.27 \pm 2.43 \mu \mathrm{mol} \mathrm{m}^{-2} \mathrm{~h}^{-1}\left(F_{d f=1}=59.576, p<0.01\right)$.

\subsection{Oxidation Rates of $\mathrm{CH}_{4}$ in the Overlying Water}

$\mathrm{CH}_{4}$ oxidation rate dynamics in the overlying water of the shrimp ponds are shown in Figure 4b. In the MRE, $\mathrm{CH}_{4}$ oxidation rate varied significantly with aquaculture stages $(p<0.05)$ and followed the order: final stage $\left(3.07 \pm 0.41 \mu \mathrm{mol} \mathrm{m} \mathrm{m}^{-2} \mathrm{~h}^{-1}\right)>$ middle stage $\left(1.99 \pm 0.11 \mu \mathrm{mol} \mathrm{m} \mathrm{m}^{-2}\right.$ $\left.\mathrm{h}^{-1}\right)>$ initial stage $\left(1.27 \pm 0.17 \mu \mathrm{mol} \mathrm{m} \mathrm{m}^{-2} \mathrm{~h}^{-1}\right)$ (Figure $4 \mathrm{~b}$ ). The oxidation rates of $\mathrm{CH}_{4}$ in the JRE also followed the same trend; however, the oxidation rates among different aquaculture stages did not differ significantly ( $p<0.05$; Figure 4 b). Overall, the mean $\mathrm{CH}_{4}$ oxidation rate from the shrimp ponds were higher in the MRE than those in the JRE $(2.23 \pm 0.22 v s$ $\left.1.97 \pm 0.23 \mu \mathrm{mol} \mathrm{m}^{-2} \mathrm{~h}^{-1}\right)$, but the difference was not significant $\left(F_{d f=1}=0.214, p=0.413\right)$.

\subsection{Physicochemical Properties of Sediment and Water}

Environmental parameters of the shrimp ponds in the studied estuaries are shown in Table S1 and Figure S2. Sediment temperature was highly variable among aquaculture stages, with significantly higher temperature occurring at the middle stages $(p<0.05)$ (Table $\mathrm{S} 1$ and Figure S2). Sediment TC, porewater concentration of TOC, DOC and DIC, and the concentration of DO and Chl- $a$ in the water column also followed a similar trend (Table S1 and Figure S2). Salinity in the porewater and water column changed significantly $(p<0.05)$ in different aquaculture stages and followed the order: initial stage $>$ middle stage $>$ final stage (Table S1 and Figure S2).

Overall, the means of sediment TC, $\mathrm{pH}, \mathrm{DO}$ concentration, Chl- $a$ concentration, atmospheric pressure, and porewater TOC and DOC concentration in the MRE were significantly larger than those in the JRE $(p<0.05)$ (Table S1 and Figure S2); however, the means of salinity, temperature and porewater DIC concentration in the MRE were significantly lower than those in the JRE $(p<0.05)$ (Table S1 and Figure S2). Compared with the MRE, the JRE had slightly lower wind speed and higher air temperature $(p>0.05)$ (Table S1). In addition, the differences 
in physicochemical properties of water at different water depths were statistically indistinguishable in each estuary during the three stages $(p>0.05)$ (Figure S2).

\section{Discussion}

\subsection{Dissolved $\mathrm{CH}_{4}$ in Sediment Porewater and Water Column}

In this study, porewater $\mathrm{CH}_{4}$ from the shrimp pond sediment in two estuaries varied greatly in different stages and the highest concentrations appeared in the middle stage (Figure 2). $\mathrm{CH}_{4}$ concentrations were significantly positively correlated with sediment temperature, porewater TOC, DOC and DIC levels ( $p<0.05$ or $p<0.01$; Table 1 ). The results indicate that higher sediment temperature and the availability of organic matter are important factors contributing to the elevated porewater $\mathrm{CH}_{4}$ concentrations during the middle stage. Similar results have been found in coastal marshs [Dutta et al., 2015; Xiang et al., 2015]. This may be due to that higher temperatures stimulate organic matter decomposition, thus providing a larger source of available substrate for microbial production of porewater $\mathrm{CH}_{4}$ [Ding et al., 2004], and consequently producing more $\mathrm{CH}_{4}$. This inference is further supported by a similar trend between the changes in $\mathrm{CH}_{4}$ release rates and porewater concentrations in the shrimp ponds (Figure 2 and Figure 4a).

There was a clear temporal pattern of $\mathrm{CH}_{4}$ concentrations in shrimp pond water, much higher concentrations appearing in the final stage (Figure 3). The significantly negative relationship between $\mathrm{CH}_{4}$ concentrations and salinity over the study period indicated the influence of salinity on $\mathrm{CH}_{4}$ levels in this ecosystem (Figure 5a). This finding is consistent with results from other estuaries [Cotovicz Jr. et al., 2016; Dutta et al., 2015]. Moreover, atmospheric pressure over the shrimp ponds also greatly varied in temporal dynamics (Table S1) [Yang et al., 2018b], similar to the trend of the $\mathrm{CH}_{4}$ concentration in water (Figure 3). The result reveals that atmospheric pressure could be another important factor responsible for temporal variation of water column $\mathrm{CH}_{4}$ concentration (Figure 5b) by affecting $\mathrm{CH}_{4}$ solubility in water [Chen et al., 2014b; Fu et al., 1996]. Furthermore, the shrimp ponds are a semi-intensive and closed ecosystem characterized by high stocking densities, low feed conversion rates and low water exchange frequency [Yang et al., 2017a]. Therefore, the increase in the ponds' water $\mathrm{CH}_{4}$ concentrations over time was probably related to the $\mathrm{CH}_{4}$ accumulation in water column due to sustained $\mathrm{CH}_{4}$ production and release from the sediment to the water column.

This study also found significant differences in sediment porewater (or water column) $\mathrm{CH}_{4}$ concentrations between the two estuaries during all sampling stages $(p<0.05$; Figure 2 and Figure 3). The higher $\mathrm{CH}_{4}$ concentration in the MRE is likely due to the low salinity and high organic matter in the sediment (Table S1), leading to high $\mathrm{CH}_{4}$ production rates and high release across the SWI (Figure $4 \mathrm{a}$ ). This inference is confirmed by the significantly positive relationship between $\mathrm{CH}_{4}$ release fluxes and salinity, TC content, or $\mathrm{CH}_{4}$ concentration (Table 2). This correlation was also observed by Borges and Abril [2011], Rao and Sarma [2016], and Dutta et al. [2013]. Methanogenic archaea is $\mathrm{pH}$ sensitive and develops quickly at a neutral or weakly alkaline environment in the coastal wetland [Chang and Yang, 2003]. Compared to the MRE, sediment $\mathrm{pH}$ in the JRE was relatively lower (average $\mathrm{pH}=6.32$ ) (Table S1), which may not favor the growth of methanogens, consequently inducing lower $\mathrm{CH}_{4}$ concentrations (Figure 2 and Figure 3 ) by reducing $\mathrm{CH}_{4}$ release fluxes (Figure 4a). Thus, higher $\mathrm{CH}_{4}$ concentrations that occurred in MRE ponds, to some extent, were also dependent 
on the differences in sediment $\mathrm{pH}$ between the two estuarial ponds.

\subsection{Dynamic Variation of $\mathrm{CH}_{4}$ Release Fluxes from Shrimp Ponds Sediment}

Temporal variations in $\mathrm{CH}_{4}$ release fluxes from the sediment were found in the current research (Figure 4a) and other wetlands and lakes [e.g., Avery et al., 2003;Bergman et al., 2000; Hu et al., 2017; Lofton et al., 2015; Vizza et al., 2017; Xing et al., 2005; Yang et al., 2008; Yang et al., 2017b]. It is generally acknowledged that temporal patterns of $\mathrm{CH}_{4}$ release are governed by temporal changes in temperature affecting the production of substrate precursors and microbial activity [e.g., Bergman et al., 2000; Inglett et al., 2012; Segers, 1998; Yang et al., 2015a]. According to correlation analysis (Table 2), sediment temperature is also a critical abiotic factor affecting the seasonal variation of sediment $\mathrm{CH}_{4}$ release fluxes in the present study. In aquatic ecosystems, the majority of $\mathrm{CH}_{4}$ is produced by the decomposition of organic matter under anaerobic conditions in the sediment [Xiao et al., 2017]. Thus, the organic matter supply in the sediment is an important factor influencing $\mathrm{CH}_{4}$ production and its subsequent release [e.g., Bergman et al., 2000; Whiting and Chanton, 1993; Xiao et al., 2017]. Although this study did not directly measure organic matter, we observed similar trends (Figure 4a and Table S1) and a significantly positive relationship between the sediment TC contents and pond $\mathrm{CH}_{4}$ release fluxes in the MRE and JRE (Table 2). The results reveal that the temporal differences in pond sediment $\mathrm{CH}_{4}$ release fluxes among the three stages in subtropical estuaries were also dependent on organic matter supply.

Average sediment $\mathrm{CH}_{4}$ release fluxes from the coastal shrimp pond in the JRE were significantly smaller than those in the MRE (11.27 \pm 2.43 vs $84.52 \pm 11.58 \mu \mathrm{mol} \mathrm{m} \mathrm{m}^{-2} \mathrm{~h}^{-1}$; $p<0.05)$, indicating a strong spatial variability in $\mathrm{CH}_{4}$ production from the coastal shrimp pond sediment. Similarly, in coastal marsh studies, the spatial variability of $\mathrm{CH}_{4}$ production and release was attributed to the direct or indirect effects of salinity [e.g., Poffenbarger et al., 2011; Sun et al., 2013; Vizza et al., 2017; Welti et al., 2017] and substrate supply [e.g., Duc et al., 2010; Kim et al., 2015; Wertebach et al., 2016; Xing et al., 2006; Yang et al., 2011; Yang et al., 2017b]. In the present study, porewater salinity in the MRE was lower than that in the JRE $(1.89 \pm 0.21 \%$ vs $7.72 \pm 0.75 \%$ ), a result of the effect of freshwater dilution caused by the interaction of precipitation, evaporation, and surface runoff. The mean levels of sediment TC in the JRE were also significantly smaller than those in the MRE $(p<0.05$, Table S1). Among the variables measured, the $\mathrm{CH}_{4}$ release fluxes values were best correlated with porewater salinity and sediment TC in the two estuaries (Table 2). These results indicated that the difference in pond sediment $\mathrm{CH}_{4}$ release fluxes between the MRE and JRE could also be attributed to salinity and substrate supply.

\section{3. $\mathrm{CH}_{4}$ Oxidation in the Overlying Water of Shrimp Ponds}

$\mathrm{CH}_{4}$ oxidation in water has been reported in a few freshwater ecosystem (e.g., lake, river, and reservoir) studies [e.g., Almeida et al., 2016; Bastviken et al., 2008; Matoušů et al., 2017; Striegl and Michmerhuizen, 1998]. The oxidation rates observed in these water columns showed very large variability among aquatic ecosystems. In this study, $\mathrm{CH}_{4}$ oxidation rates in the overlying water in the shrimp ponds were calculated based on the time-dependent reduction in dissolved $\mathrm{CH}_{4}$ concentrations in the incubated water samples. During the experimental period, none of the samples indicated net $\mathrm{CH}_{4}$ production in the shrimp pond water column, suggesting the oxidation of $\mathrm{CH}_{4}$ in the shrimp ponds (Figure 4b). However, an unexpected but interesting result of the current study was that $\mathrm{CH}_{4}$ oxidation rates were 
always maintained at a relatively lower level, even though the water column contained a high level of DO (Figure S2). The $\mathrm{CH}_{4}$ oxidation rates in the overlying water of the shrimp ponds at two subtropical estuaries ranged between 0.36 and $5.66 \mu \mathrm{mol} \mathrm{m} \mathrm{m}^{-2} \mathrm{~h}^{-1}$, much lower than those reported in freshwater ecosystems $\left(0.04-0.16 \mathrm{~mol} \mathrm{~m}^{-2} \mathrm{~h}^{-1}\right)$ [e.g., Bastviken et al., 2008; Matoušu et al., 2017; Sawakuchi et al., 2016]. This may be attributed to the shrimp ponds' polyhaline characteristics that maintain a relatively higher salinity range (Figure S2) resulting in a weak $\mathrm{CH}_{4}$ oxidation in the water column [Dutta et al., 2015].

Despite relatively lower water column $\mathrm{CH}_{4}$ oxidation rates in the shrimp ponds, there were large variations in $\mathrm{CH}_{4}$ oxidation among aquaculture stages (Figure 4b). A similar phenomenon was also reported in other aquatic environments. Multiple studies found that the temporal changes of $\mathrm{CH}_{4}$ oxidation rates were governed by temperature variation that affected methanotroph activity [e.g., Dutta et al., 2015; Lofton et al., 2014; Matoušu et al., 2017; Osudar et al., 2015]. However, $\mathrm{CH}_{4}$ oxidation rates in the subtropical shrimp ponds did not seem to be affected by the seasonal variability in temperature (Figure $4 \mathrm{~b}$ and Figure S2). Similar results were also observed by Abril. [2007] and Roland et al. [2017], who found that the water column substrate (i.e., $\mathrm{CH}_{4}$ concentrations) played a crucial role affecting the temporal variability in the $\mathrm{CH}_{4}$ oxidation rates. In this study, $\mathrm{CH}_{4}$ concentrations in water of two estuaries increased in the order: final stage > middle stage > initial stage (Figure 3), which was similar to the trend of $\mathrm{CH}_{4}$ oxidation rates (Figure 4b). This study also found the strongest relationships between $\mathrm{CH}_{4}$ oxidation rate measurements from each estuary and the corresponding water column $\mathrm{CH}_{4}$ concentrations (Figure 6a). Therefore, variation of $\mathrm{CH}_{4}$ oxidation rates from the shrimp ponds were possibly controlled by water column substrate $\left(\mathrm{CH}_{4}\right.$ concentrations) shifts. Because $\mathrm{CH}_{4}$ oxidation also needs oxygen, the process of $\mathrm{CH}_{4}$ oxidation is a section of the biological oxygen demand [Matoušu et al., 2017]. Thus, we hypothesize that the temporal patterns in $\mathrm{CH}_{4}$ oxidation rates from the shrimp ponds, to some extent, are dependent on the supply of dissolved oxygen, which is probably more favorable for the methanotrophs growth. Although methanotroph data are unavailable in the present study, the $\mathrm{CH}_{4}$ oxidation rates from the ponds' overlying water showed a significantly positive relationship with dissolved oxygen (Figure 6b), which lends indirect support to the above hypothesis.

\subsection{Implications of Aquaculture Pond $\mathrm{CH}_{4}$ Biogeochemical Cycling}

In an earlier study, Yang et al. [2018] estimated that $\mathrm{CH}_{4}$ emissions from the aquaculture shrimp ponds into the atmosphere in the two subtropical estuaries ranged from 2.5 to 189.4 $\mathrm{mg} \mathrm{m} \mathrm{m}^{-2} \mathrm{~h}^{-1}$, with mean values of $47.8 \mathrm{mg} \mathrm{m}^{-2} \mathrm{~h}^{-1}$. It is worth noting that the $\mathrm{CH}_{4}$ emissions fluxes in subtropical estuarine aquaculture ponds were substantially higher than those from the freshwater aquaculture systems [e.g., Da Silva et al., 2018; Hu et al., 2014, 2016; Liu et al., 2015; Wu et al., 2018; ] and were also one to three orders of magnitude higher than those observed in most reservoirs and lakes in temperate, boreal, and Arctic regions [e.g., Gerardo-Nieto et al., 2017; Huttunen et al., 2002; Natchimuthu et al., 2016; Zhu et al., 2010]. The range of $\mathrm{CH}_{4}$ emissions from aquaculture shrimp ponds in the two subtropical estuaries were also substantially higher than those from the coastal marsh in Liaohe Delta (0.32 to 6.40 $\mathrm{mg} \mathrm{m}^{-2} \mathrm{~h}^{-1}$ ) [Olsson et al., 2015], Yellow River estuary ( -0.80 to $\left.0.48 \mathrm{mg} \mathrm{m}^{-2} \mathrm{~h}^{-1}\right)$ [Sun et al., 2013], Min River estuary (0.80 to $13.28 \mathrm{mg} \mathrm{m}^{-2} \mathrm{~h}^{-1}$ ) [Tong et al., 2010], and Mobile Bay 
estuary $\left(0.00\right.$ to $\left.4.00 \mathrm{mg} \mathrm{m}^{-2} \mathrm{~h}^{-1}\right)$ [Wilson et al., 2015]. In addation, Yang et al. [2017b] found that the conversion of brackish marsh in the Min River Estuary to shrimp ponds could considerably increase $\mathrm{CH}_{4}$ emissions during the culture period. These results indicate that subtropical estuarine aquaculture ponds could be important sources of atmospheric $\mathrm{CH}_{4}$ and thus should not be overlooked in greenhouse gas accounting for their contributions to global climate change. China's economy developed rapidly in the last four decades with the cost of environmental degradation [Yang et al., 2013a; Yang et al., 2018a], while environmental protection has received increasing attention in the last years [Yang 2014; Yang et al., 2015b]. Considering the world momentum of mitigating global warming, effective approaches are needed to reduce $\mathrm{CH}_{4}$ emissions from aquaculture ecosystem in both China and other countries.

Our previous study have reported that also there were large variations in $\mathrm{CH}_{4}$ emissions fluxes from aquaculture ponds among estuaries, with high fluxes occurred Min River Estuary (86.01 $\mathrm{mg} \mathrm{m}^{-2} \mathrm{~h}^{-1}$ ) and low fluxes occurred Jiulong River Estuary $\left(9.64 \mathrm{mg} \mathrm{m}^{-2} \mathrm{~h}^{-1}\right.$ ) [Yang et al., 2018b]. The variations pattern of $\mathrm{CH}_{4}$ emission fluxes was highly similar to that of sediment $\mathrm{CH}_{4}$ release rates (Figure 4a) and porewater $\mathrm{CH}_{4}$ concentrations (Figure 2). The result indicate that high $\mathrm{CH}_{4}$ emissions were accompanied by high sediment $\mathrm{CH}_{4}$ production and porewater $\mathrm{CH}_{4}$ concentrations. The high variability of $\mathrm{CH}_{4}$ emission and other biogeochemical processes from mariculture ponds is commonly related to multiple environmental factors, but low salinity is necessary to produce high $\mathrm{CH}_{4}$ emission fluxes. In addition, the mean survival rate and yield of shrimp in the MRE ponds amounted to $65 \%$ and $0.35 \mathrm{~kg} \mathrm{~m}^{-2}$, respectively, which were lower than those in the JRE ponds, at $70 \%$ and $0.41 \mathrm{~kg}$ $\mathrm{m}^{-2}$, respectively [Yang et al., 2018b]. This implies that increasing the salinity level of aquaculture ponds might be an important strategy to mitigate $\mathrm{CH}_{4}$ emissions and increase aquaculture animal (e.g., shrimp) production. Further studies are merited to investigate the effect of salinity on methanotroph in aquaculture ponds.

\subsection{Limitation and Future Research}

Same as many studies, there are limitations in the current study. Firstly, $\mathrm{CH}_{4}$ dynamics investigation was conducted in two estuaries in June, August, and October during the aquaculture period. The limited number of studying times and estuaries might limit the wide application of our results. Obviously, future studies including longer research period and more sites, especially, covering different aquaculture pond type, specific aquaculture management practice and reclamation history, will expand our understanding of $\mathrm{CH}_{4}$ dynamics in mariculture systems. Second, this study examined the effect of key environmental factors on $\mathrm{CH}_{4}$ dynamics in aquaculture ponds, while the contribution of microbial abundance and activity (methanogens, methanotrophs, and sulfate reducting bacteria), and methanogenic substrates may also be very important to control $\mathrm{CH}_{4}$ biogeochemical cycling in estuarine aquaculture ponds. Thus, more studies are still needed to further understand the driving mechanism for $\mathrm{CH}_{4}$ biogeochemical cycles in estuarine aquaculture ponds. Recently, Oliveira Junior et al. [2019] reported that fish bioturbation can significantly decrease $\mathrm{CH}_{4}$ emission by increasing sediment oxygenation. This study analyzed $\mathrm{CH}_{4}$ dynamics based on laboratory incubation experiments. Future in situ study on bioturbation effect will further improve our understanding of $\mathrm{CH}_{4}$ dynamics in aquaculture ponds. 


\section{Conclusions}

This study researched the variations of dissolved concentrations, net sediment release, and overlying water oxidation of methane in three aquaculture stages in shrimp ponds in two estuaries, MRE and JRE, in Southeast China. Methane dynamics in subtropical aquaculture ponds were controlled by multiple environmental factors including physicochemical factors, such as salinity, temperature, DO, and meteorological parameter, and biological factors, such as biological metabolism. Despite higher $\mathrm{CH}_{4}$ oxidation rates in the MRE than those in the $\mathrm{JRE}, \mathrm{CH}_{4}$ release rates in the MRE pond sediments were high and also large levels of $\mathrm{CH}_{4}$ accumulated in the porewater because of low porewater salinity, high sediment organic matter content, and the use of noncompetitive substrates by methanogenic microorganisms [Chuang et al., 2016]. This resulted in large $\mathrm{CH}_{4}$ release from surface sediment to water column and then to the atmosphere. Combined with the previous study [Yang et al., 2018b], our results indicate that aquaculture ponds in the subtropical estuaries are some potential "hotspots" of $\mathrm{CH}_{4}$ biogeochemical cycling and may contribute a substantial fraction to China's total wetland $\mathrm{CH}_{4}$ emission. Achieving a tradeoff between carbon mitigation and aquaculture development will be a big challenge. The high spatial $\mathrm{CH}_{4}$ biogeochemical cycle variation between estuaries implies that increasing the salinity level of ponds water and higher feed utilization efficiency would help to mitigate $\mathrm{CH}_{4}$ emissions from aquaculture ponds. However, this study results from a limited area across a limited time period. In the future work, the need to strengthen the frequency of sampling in situ at longterm and different spatial scales, and to further identify the effect of microbial abundance and activity on $\mathrm{CH}_{4}$ biogeochemical cycle in coastal aquaculture ponds to reveal the causalities of spatial and temporal variations.

\section{Acknowledgements}

This research was financially supported by National Science Foundation of China (No. 41801070, 41671088), Research Grants Council of the Hong Kong Special Administrative Region, China (CUHK458913), CUHK Direct Grant (SS15481), Open Research Fund Program of Jiangsu Key Laboratory of Atmospheric Environment Monitoring \& Pollution Control, and Minjiang Scholar Programme. We would like to thank Wei-Ning Du and Jing-Yu Zhang of the School of Geographical Sciences, Fujian Normal University, for their assistance in the field. The data used in this study are available in the Article File, Data Set File and Supporting Material File.

\section{References}

Abril, G., M. V. Commarieu, and F. Guerin (2007), Enhanced methane oxidation in an estuarine turbidity maximum, Limnol. Oceanogr., 52, 470-475, http://dx.doi.org/10.4319/lo.2007.52.1.0470.

Almeida, R. M., G. N. Nóbrega, P. C. Junger, A. V. Figueiredo, A. S. Andrade, C. G. B. de Moura, D. Tonetta, E. S. Oliveira Jr., F. Araújo, F. Rust, J. M. Piñeiro-Guerra, J. R. Mendonça Jr., L. R. Medeiros, L. Pinheiro, M. Miranda, M. R. A. Costa, M. L. Melo, R. L. G. Nobre, T. Benevides, F. Roland, J. de Klein, N. O. Barros, R. Mendonça, V. Becker, V. L. M. Huszar, and S. Kosten (2016), High primary production contrasts with intense carbon emission in a eutrophic tropical reservoir, Front. Microbiol., 7, 717, http://dx.doi.org/10.3389/fmicb.2016.00717.

Allen, D. E., R. C. Dalal, H. Rennenberg, R. L. Meyer, S. Reeves, S. Schmidt (2007) Spatial and temporal variation of nitrous oxide and methane flux between subtropical mangrove sediments and the atmosphere, Soil Biol. Biochem., 39, 622-631. 
Avery, G. B., R. D. Shannon, J. R. White, C. S. Martens, and M. J. Alperin (2003), Controls on methane production in a tidal freshwater estuary and a peatland: methane production via acetate fermentation and $\mathrm{CO}_{2}$ reduction, Biogeochemistry 62, 19-37.

Bastviken, D., J. J. Cole, M. L. Pace, and M. C. Van de Bogert (2008), Fates of methane from different lake habitats: Connecting whole-lake budgets and $\mathrm{CH}_{4}$ emissions, J. Geophys. Res., 113, G02024, doi:10.1029/2007JG000608

Bastviken, D., L. J. Tranvik, J. A. Downing, P. M. Crill, and A. Enrich-Prast (2011), Freshwater methane emissions offset the continental carbon sink, Science 331, 50.

Bergman, I., M. Klarqvist, and M. Nilsson (2000), Seasonal variation in rates of methane production from peat of various botanical origins: effects of temperature and substrate quality, FEMS Microbiol. Ecol., $33,181-189$.

Blees, J., H. Niemann, M. Erne, J. Zopfi, C. J. Schubert, and M. F. Lehmann (2015), Spatial variations in surface water methane super-saturation and emission in Lake Lugano, southern Switzerland, Aquat. Sci., 77: 535-545, http://dx.doi.org/10.1007/s00027-015-0401-z

Borges, A.V., and G. Abril (2011), Carbon dioxide and methane dynamics in estuaries, p. 119-161. In W. Eric and M. Donald [eds.], Treatise on estuarine and coastal science. Academic Press.

Bridgham, S. D., H. Cadillo-Quiroz, J. K. Keller, and Q. L. Zhuang (2013), Methane emissions from wetlands: Biogeochemical, microbial, and modeling perspectives from local to global scales. Glob. Chang. Biol., 19, 1325-1346, doi: 10.1111/gcb.12131S

Casillas-Hernández, R., F. Magallón-Barajas, G. Portillo-Clarck, and F. Páez-Osuna (2006), Nutrient mass balances in semi-intensive shrimp ponds from Sonora, Mexico using two feeding strategies: trays and mechanical dispersal, Aquaculture 258, 289-298.

Chang, T. C., and S. S. Yang (2003), Methane emission from wetland in Taiwan, Atmos. Environ., 37, 4551-4558.

Chen, Y., S. L. Dong, F. Wang, Q. F. Gao, and X. L. Tian (2016), Carbon dioxide and methane fluxes from feeding and no-feeding mariculture ponds, Environ. Pollut., 212, 489-497.

Chen, Z. H., N. W. Chen, Y. Q. Wu, Q. L. Mo, X. P. Zhou, T. Lu, Y. Tian (2014a), Sediment-water flux and processes of nutrients and gaseous nitrogen release in a China river reservoir, Environ. Sci., 35(9), 3325-3335. (in Chinese).

Chen, Y., F. Mutelet, and J. N. Jaubert (2014b), Solubility of carbon dioxide, nitrous oxide and methane in ionic liquids at pressures close to atmospheric, Fluid Phase Equilibria., 372, 26-33.

Chuang, P.C., M. B. Young, A. W. Dale, L.G. Miller, J. A. Herrera-Silveira, and A. Paytan (2017), Methane fluxes from tropical coastal lagoons surrounded by mangroves, Yucatán, Mexico, J. Geophys. Res. Biogeosci., 122, doi: 10.1002/2017JG003761

Cotovicz., L. C., B. A. Knoppers, N. Brandini, D. Poirier, S. J. Costa Santos, and G. Abril (2016), Spatio-temporal variability of methane $\left(\mathrm{CH}_{4}\right)$ concentrations and diffusive fluxes from a tropical coastal embayment surrounded by a large urban area (Guanabara Bay, Rio de Janeiro, Brazil), Limnol. Oceanogr., 61, S238-S252.

Cowan, J. L. W., and W. R. Boynton (1996), Sediment-water oxygen and nutrient exchanges along the longitudinal axis of Chesapeake Bay: Seasonal patterns, controlling factors and ecological significance, Estuaries 19(3), 562-580, doi: 10.2307/1352518.

Da Silva, M. G., A. P. Packer, F. G. Sampaio, L. Marani, E. V. C. Mariano, R. A. A. Pazianotto, W. J. Ferreira, and P. C. Alvalá (2018), Impact of intensive fish farming on methane emission in a tropical hydropower reservoir, Climatic Change doi:10.1007/s10584-018-2281-4

De Vittor, C., J. Faganeli, A. Emili, S. Covelli, S. Predonzani, and A. Acquavita (2012), Benthic fluxes of oxygen, carbon and nutrients in the Marano and Grado Lagoon (northern Adriatic Sea, Italy), Estuar. Coast. Shelf S., 113, 57-70.

Ding, W. X., Z. C. Cai, and H. Tsuruta (2004), Cultivation, nitrogen fertilization, and set-aside effects on methane uptake in a drained marsh soil in northeast China, Glob. Chang. Biol., 10, 1801-1809.

Dinsmore, K. J., U. M. Skiba, M. F. Billett, and R. M. Rees (2009), Effect of water table on greenhouse gas emissions from peatland mesocosms, Plant Soil 318, 229-242.

Duc, N. T., P. Crill, and D. Bastviken (2010), Implications of temperature and sediment characteristics on methane formation and oxidation in lake sediments, Biogeochemistry 100, 185-196. http://dx.doi.org/10.1007/s10533-010-9415-8 
Dutta, M. K., R. Mukherjee, T. K. Jana, and S. K. Mukhopadhyay (2015), Biogeochemical dynamics of exogenous methane in an estuary associated to a mangrove biosphere; The Sundarbans, NE coast of India, Mar. Chem., 170, 1-10.

Dutta, M. K., C. Chowdhury, T. K. Jana, and S. K. Mukhopadhyay (2013), Dynamics and exchange fluxes of methane in the estuarine mangrove environment of Sundarbans, NE coast of India, Atmos. Environ., 77, 631-639.

FAO (2016), The State of World Fisheries and Aquaculture, 2014. Food and Agricultural Organization of the United Nations, Rome, Italy.

Fisheries Department of Agriculture Ministry of China (2015), China Fisheries Statistical Yearbook, China Agriculture Press, Beijing (in Chinese).

Fu, X. T., Z. P. Wang, and S. F. Lu (1996), Solubility of gases in water: mechanisms and calculation, Sci. China (B) 26(2), 124-130. (in Chinese)

Gerardo-Nieto, O., M. S. Astorga-España, A. Mansilla, and F. Thalasso (2017), Initial report on methane and carbon dioxide emission dynamics from sub-Antarctic freshwater ecosystems: a seasonal study of a lake and a reservoir, Sci. Total Environ., 593, 144-154.

Han, H. J., X. X. Lu, D. F. Burger, U. M. Joshi, and L. Zhang (2014), Nitrogen dynamics at the sediment-water interface in a tropical reservoir, Ecol. Eng., 73, 146-153.

Hu, M. J., H. C. Ren, P. Ren, J. B. Li, B. J. Wilson, and C. Tong (2017), Response of gaseous carbon emissions to low-level salinity increase in tidal marsh ecosystem of the Min River estuary, southeastern China, J. Environ. Sci., 52, 210-222, http://dx.doi.org/10.1016/j.jes.2016.05.009

Hu, Z., J. W. Lee, K. Chandran, S. Kim, and S. K. Khanal (2012), Nitrous oxide $\left(\mathrm{N}_{2} \mathrm{O}\right)$ emission from aquaculture: a review, Environ. Sci. Technol., 46 (12), 6470-6480.

Hu, Z., J. W. Lee, K. Chandran, S. Kim, K. Sharma, and S. K. Khanal (2014), Influence of carbohydrate addition on nitrogen transformations and greenhouse gas emissions of intensive aquaculture system, Sci. Total. Environ., 470, 193-200.

Hu, Z. Q., S. Wu, C. Ji, J. W. Zou, Q. S. Zhou, and S. W. Liu (2016), A comparison of methane emissions following rice paddies conversion to crab-fish farming wetlands in southeast China, Environ. Sci. Pollut. Res., 23(2),1505-1515, doi:0.1007/s11356-015-5383-9

Huttunen, J. T., J. Alm, A. Liikanen, S. Juutinen, T. Larmola, T. Hammar, J. Silvola, and P. J. Martikainen (2003), Fluxes of methane, carbon dioxide and nitrous oxide in boreal lakes and potential anthropogenic effects on the aquatic greenhouse gas emissions, Chemosphere 52, 609-621.

Huttunen, J. T., T. S. Väisänen, S. K. Hellsten, M. Heikkinen, H. Nykänen, H. Jungner, A. Niskanen, M. O. Virtanen, O. V. Lindqvist, O. S. Nenonen, and P. J. Martikainen (2002), Fluxes of $\mathrm{CH}_{4}, \mathrm{CO}_{2}$, and $\mathrm{N}_{2} \mathrm{O}$ in hydroelectric reservoirs Lokka and Porttipahta in the northern boreal zone in Finland, Glob. Biogeochem. Cycl., 16 (1), https://doi.org/10.1029/2000GB001316.

Inglett, K. S., P. W. Inglett, K. R. Reddy, and T. Z. Osborne (2012), Temperature sensitivity of greenhouse gas production in wetland soils of different vegetation, Biogeochemistry 108, 77-90.

IPCC (2013), The Physical Science Basis. Contribution of Working Group I to the Fifth Assessment Report of the Intergovernmental Panel on Climate Change, p. 1535. In T. F. Stocker and others [eds.], Climate Change 2013. Cambridge Univ. Press.

Kim, S. Y., A. J. Veraart, M. Meima-Franke, and P. L. E. Bodelier (2015), Combined effects of carbon, nitrogen and phosphorus on $\mathrm{CH}_{4}$ production and denitrification in wetland sediments, Geoderma 259, 354-361.

Knox, S. H., J. H. Matthes, C. Sturtevant, P. Y. Oikawa, J. Verfaillie, and D. Baldocchi (2016), Biophysical controls on interannual variability in ecosystem-scale $\mathrm{CO}_{2}$ and $\mathrm{CH}_{4}$ exchange in a California rice paddy, J. Geophys. Res. Biogeosci., 121, 978-1001, doi:10.1002/2015JG003247

Lai, D. Y. F., (2009), Methane dynamics in northern peatlands: A review, Pedosphere 19(4), 409-421.

Liu, S. W., Z. Q. Hu, S. Wu, S. Q. Li, Z. F. Li, and J. W. Zou (2015), Methane and nitrous oxide emissions reduced following conversion of rice paddies to inland crab-fish aquaculture in southeast China, Environ. Sci. Technol., 50(2), 633-642.

Lofton, D. D., S. C. Whalen. and A. E. Hershey (2014), Effect of temperature on methane dynamics and evaluation of methane oxidation kinetics in shallow Arctic Alaskan lakes, Hydrobiologia 721(1), 209-222.

Lofton, D. D., S. C. Whalen, and A. E. Hershey (2015), Vertical sediment distribution of methanogenic pathways in two shallow Arctic Alaskan lakes, Polar Biol., 38(6), 815-827. 
Matoušů, A., R. Osudar, K. Šimek, and I. Bussmann (2017), Methane distribution and methane oxidation in the water column of the Elbe estuary, Germany, Aquat. Sci., 79(3), 443-458. http://dx.doi.org/10.1007/s00027-016-0509-9

Matos, C. R. L., U. Mendoza, R. Diaz, M. Moreira, A. L. Belem, E. Metzger, A. L. S. Albuquerque, and W. Machado (2016), Nutrient regeneration susceptibility under contrasting sedimentary conditions from the Rio de Janeiro coast, Brazil, Mar. Pollut. Bull., 108, 297-302.

Martinez-Cruz, K., R. Gonzalez-Valencia, A. Sepulveda-Jauregui, F. Plascencia-Hernandez, Y. Belmonte-Izquierdo, and F. Thalasso (2017), Methane emission from aquatic ecosystems of Mexico City, Aquat. Sci., 79, 159-169.

Musenze, R. S., L. Fan, A. Grinham, U. Werner, D. Gale, J. Udy, and Z. G. Yuan (2016), Methane dynamics in subtropical freshwater reservoirs and the mediating microbial communities, Biogeochemistry 128, 233-255, http://dx.doi.org/10.1007/s10533-016-0206-8

Natchimuthu, S., I. Sundgren, M. Gålfalk, L. Klemedtsson, P. Crill, A. Danielsson, and D. Bastviken (2016), Spatio-temporal variability of lake $\mathrm{CH}_{4}$ fluxes and its influence on annual whole lake emission estimates, Limnol. Oceanogr., 61, S13-S26.

Neue, H. U., J. L. Gaunt, Z. P. Wang, P. Becker-Heidmann, and C. Quijano (1997), Carbon in tropical wetlands, Geoderma 79, 163-185.

Oliveira Junior, E.S., R. J. M. Temmink, B. F. Buhler, R. M. Souza, N. Resende, T. Spanings, C. C. Muniz, L. P. M. Lamers, and S. Kosten (2019) Benthivorous fish bioturbation reduces methane emissions, but increases total greenhouse gas emissions, Freshwater Biol., 64(1), 197-207 , http://dx.doi.org/10.1111/fwb.13209

Olsson, L., S. Ye, X. Yu, M. Wei, K. W. Krauss, and H. Brix (2015) Factors in fluencing $\mathrm{CO}_{2}$ and $\mathrm{CH}_{4}$ emissions from coastal wetlands in the Liaohe Delta, Northeast China, Biogeosciences 12, 4965 $-4977$.

Osudar, R., A. Matoušů, M. Alawi, D. Wagner, and I. Bussmann (2015), Environmental factors affecting methane distribution and bacterial methane oxidation in the German Bight (North Sea), Estuar. Coast. Shelf S., 160, 10-21, http://dx.doi.org/doi:10.1016/j.ecss.2015.03.028

Palma-Silva, C., C. C. Marinho, E. F. Albertoni, I. B. Giacomini, M. P. Figueiredo Barros, L. M.

Furlanetto, C. R. T. Trindade, and F. D. A. Esteves (2013), Methane emissions in two small shallow neotropical lakes: The role of temperature and trophic level, Atmos. Environ., 81, 373-379, doi:10.1016/j.atmosenv.2013.09.029.

Poffenbarger, H. J., B. A. Needelman, and J. P. Megonigal (2011), Salinity influence on methane emissions from tidal marshes, Wetlands 31, 831-842.

Purdy, K., D. Nedwell, and T. Embley (2003) Analysis of the sulfate-reducing bacterial and methanogenic archaeal populations in contrasting Antarctic sediments, Appl. Environ. Microbiol., 69, 3181 -3191 .

Qu, W. C., R. J. Morrison, R. J. West, and C. W. Su (2007), Spatial and temporal variability in dissolved inorganic nitrogen fluxes at the sediment-water interface in Lake Illawarra, Australia, Water Air Soil Poll., 186, 15-28, http://dx.doi.org/10.1007/s11270-007-9459-0

Rao, G. D., and V. V. S. S. Sarma (2016), Variability in concentrations and fluxes of methane in the Indian estuaries. Estuar. Coast., 39, 1639-1650, http://dx.doi.org/10.1007/s12237-016-0112-2

Roland, F. A. E., F. Darchambeau, C. Morana, S. Bouillon, and A. V. Borges (2017), Emission and oxidation of methane in a meromictic, eutrophic and temperate lake (Dendre, Belgium), Chemosphere 168, 756-764.

Sawakuchi, H. O., D. Bastviken, A. O. Sawakuchi, A. O. Sawakuchi, N. D. Ward, C. D. Borges, S. M. Tsai, J. E. Richey, M. V. R. Ballester, and A. V. Krusche (2016), Oxidative mitigation of aquatic methane emissions in large Amazonian rivers, Global Change Biol., 22, 1075-1085, http://dx.doi.org/10.1111/gcb.13169

Segers, R (1998), Methane production and methane consumption: a review of processes underlying wetland methane fluxes, Biogeochemistry 41, 23-51.

Striegl, R. G., and C. M. Michmerhuizen (1998), Hydrologic influence on methane and carbon dioxide dynamics at two north-central Minnesota lakes, Limnol. Oceanogr., 43, 1519-1529.

Sun, Z. G., L. L. Wang, H. Q. Tian, H. H. Jiang, X. J. Mou, and W. L. Sun (2013), Fluxes of nitrous oxide and methane in different coastal Suaeda salsa marshes of the Yellow River estuary, China, Chemosphere 90(2), 856-865, http://dx.doi.org/10.1016/j.chemosphere.2012.10.004 
Taipale, S. J., and E. Sonninen (2009), The influence of preservation method and time on the $\delta^{13} \mathrm{C}$ value of dissolved inorganic carbon in water samples, Rapid Commun. Mass Sp., 23(16), 2507-2510.

Tong, C., W. Q. Wang, C. S. Zeng, and R. Marrs (2010), Methane emissions from a tidal marsh in the Min River estuary, southeast China, J. Environ. Sci. Heal. A., 45, 506-516.

Venkiteswaran, J. J., S. L. Schiff, St. V. L. Louis, C. J. D. Matthews, N. M. Boudreau, E. M. Joyce, K. G. Beaty, and R. A. Bodaly (2013) Processes affecting greenhouse gas production in experimental boreal reservoirs. Global Biogeochem. Cycles 27(2), 567-577.

Verdegem, M. C. J., and R. H. Bosma (2009), Water withdrawal for brackish and inland aquaculture, and options to produce more fish in ponds with present water use, Water Policy 11, 52-68.

Vizza, C., W. E. West, S. E. Jones, J. A. Hart, and G. A. Lamberti (2017), Regulators of coastal wetland methane production and responses to simulated global change, Biogeosciences 14, 431-446.

Wang, D. Q., Y. J. Tan, Z. J. Yu, Y. J. Li, S. Q. Chang, H. G. Deng, B. B. Hu, and Z. L. Chen (2015), Nitrous oxide production in river sediment of highly urbanized area and the effects of water quality, Wetlands 35, 1213-1223, http://dx.doi.org/10.1007/s13157-015-0708-5

Wang H. T., X. R. Yang, and T. L. Zheng (2013), Impact of simulated tide and vegetation on the wetland greenhouse gases fluxes, Acta Scientiae Circumstantiae, 33(12), 3376-3385 (in Chinese).

Wang, Z. P., C. W. Lindau, R. D. Delaune, W. H. Patrick Jr. (1993) Methane emission and entrapment in flooded rice soils as affected by soil properties. Biol. Fertil. Soils 16(3), 163-168.

Wanninkhof, R (1992), Relationship between wind speed and gas exchange over the ocean, J. Geophys. Rese., (Oceans) 97(C5), 7373-7382.

Welti, N., M. Hayes, and D. Lockington (2017), Seasonal nitrous oxide and methane emissions across a subtropical estuarine salinity gradient, Biogeochemistry 132, 55-69.

Wertebach, T. M., K. H. Knorr, M. Lordieck, N. Tretiakov, C. Blodau, N. Hölzel, and T. Kleinebecker (2016), Relationships between vegetation succession, pore water chemistry and $\mathrm{CH}_{4}$ and $\mathrm{CO}_{2}$ production in a transitional mire of Western Siberia (Tyumen Oblast), Wetlands 36, 863-874.

Whalen, S.C. (2005) Biogeochemistry of methane exchange between natural wetlands and the atmosphere, Environ. Eng. Sci., 22, 73-94.

Whiting, G. J., and J. P. Chanton (1993), Primary production control of methane emission from wetlands, Nature 364, 794-795.

Wilson, B.J., B. Mortazavi, and R. P. Kiene (2015) Spatial and temporal variability in carbon dioxide and methane exchange at three coastal marshes along a salinity gradient in a northern Gulf of Mexico estuary, Biogeochemistry 123, 329-347.

World Meteorological Organization (2016), WMO Greenhouse Gas Bulletin No.12 (October 2016), https://library.wmo.int/opac/doc_num.php?explnum_id=3084.pdf.

Wu, S., Z. Q. Hu, T. Hu, J. Chen, K. Yu, J. W. Zou, and S. W. Liu (2018), Annual methane and nitrous oxide emissions from rice paddies and inland fish aquaculture wetlands in southeast China, Atmos. Environ., 175, 135-144.

Xiang, J., D. Y. Liu, W. X. Ding, J. J. Yuan, and Y. X. Lin (2010), Invasion chronosequence of Spartina alterniflora on methane emission and organic carbon sequestration in a coastal salt marsh, Atmos. Environ., 112, 72-80.

Xiao, Q. T., M. Zhang, Z. H. Hu, Y. Q. Gao, C. Hu, C. Liu, S. D. Liu, Z. Zhang, J. Y. Zhao, W. Xiao, and $X$. Lee (2017), Spatial variations of methane emission in a large shallow eutrophic lake in subtropical climate, J. Geophys. Res. Biogeosci., 122(7), 1597-1614, doi:10.1002/2017JG003805

Xing, Y.P., P. Xie, H. Yang, L. Y. Ni, Y. S. Wang, and W. H. Tang (2004), Diel variation of methane fluxes in summer in a eutrophic subtropical lake in china, J. Freshwat. Ecol., 19, 639-644.

Xing, Y. P., P. Xie, H. Yang, L. Y. Ni, Y. Wang, and K. W. Rong (2005), Methane and carbon dioxide fluxes from a shallow hypereutrophic subtropical lake in china, Atmos. Environ., 39, 5532-5540.

Xing, Y. P., P. Xie, H. Yang, A. P. Wu, and L. Y. Ni (2006), The change of gaseous carbon fluxes following the switch of dominant producers from macrophytes to algae in a shallow subtropical lake of china, Atmos. Environ., 40, 8034-8043.

Xiong, Y. H., F. Wang, X. T. Guo, F. Liu, and S. L. Dong (2017), Carbon dioxide and methane fluxes across the sediment-water interface in different grass carp Ctenopharyngodon idella polyculture models. Aquacult, Environ. Interact., 9: 45-56, doi, 10.3354/aei00214 
Yamamoto, S., J. B. Alcauskas, and T. E. Crozier (1976), Solubility of methane in distilled water and seawater, J. Chem. Eng. Data 21, 78-80, http://dx.doi.org/10.1021/je60068a029

Yang, H. (2014), China must continue the momentum of green law, Nature 509, 535-535.

Yang, H., T. Andersen, P. Dörsch, K. Tominaga, J. -E. Thrane, and D. O. Hessen (2015a), Greenhouse gas metabolism in Nordic boreal lakes, Biogeochemistry 126, 211-225.

Yang, H., R. J. Flower, J. R. Thompson (2013a). Sustaining China's Water Resources. Science 339, 141-141.

Yang, H., X. Huang, J. R. Thompson, R. J. Flower (2015b). Enforcement key to China's environment, Science 347, 834-835.

Yang, H., M. Ma, J. R. Thompson, R. J. Flower (2018). Waste management, informal recycling, environmental pollution and public health, J. Epidemiil. Commun. H., 72, 237-243.

Yang, H., Y. P. Xing, P. Xie, L. Y. Ni, and K. W. Rong (2008), Carbon source/sink function of a subtropical, eutrophic lake determined from an overall mass balance and a gas exchange and carbon burial balance, Environ. Pollut., 151, 559-568.

Yang, H., P. Xie, L. Y. Ni, and R. J. Flower (2011), Underestimation of $\mathrm{CH}_{4}$ emission from freshwater lakes in china, Environ. Sci. Technol., 45, 4203-4204.

Yang, J. S., J. S. Liu, X. J. Hu, X. X.Li, Y. Wang, and H. Y. Li (2013b), Effect of water table level on $\mathrm{CO}_{2}$, $\mathrm{CH}_{4}$ and $\mathrm{N}_{2} \mathrm{O}$ emissions in a freshwater marsh of Northeast China, Soil Biol. Biochem. 61, 52-60.

Yang, P., Q. H. He, J.F. Huang, and C. Tong (2015c), Fluxes of greenhouse gases at two different aquaculture ponds in the coastal zone of southe astern China, Atmos. Environ., 115, 269-277.

Yang, P., D. Y. F. Lai, B. S. Jin, D. Bastviken, L. S. Tan, and C. Tong (2017a), Dynamics of dissolved nutrients in the aquaculture shrimp ponds of the Min River estuary, China: Concentrations, fluxes and environmental loads, Sci. Total Environ., 603-604, 256-267.

Yang, P., D. Bastviken, D. Y. F. Lai, B. S. Jin, X. J. Mou, C. Tong, and Y. C. Yao (2017b), Effects of coastal marsh conversion to shrimp aquacultu re pond s on $\mathrm{CH}_{4}$ and $\mathrm{N}_{2} \mathrm{O}$ emissions, Estuar. Coast. Shelf Sci., 199, 125-131.

Yang, P., M. H. Wang, D. Y. F. Lai, K. P. Chun, J. F. Huang, S. A. Wan, D. Bastviken, and C. Tong (2019), Methane dynamics in an estuarine brackish Cyperus malaccensis marsh: Production and porewater concentration in soils, and net emissions to the atmosphere over five years, Geoderma 337, 132-142.

Yang, P., Y. F. Zhang, D. Y. F. Lai, L. S. Tan, B. S. Jin, and C. Tong (2018b), Fluxes of carbon dioxide and methane across the water-atmosphere interface of aquaculture shrimp ponds in two subtropical estuaries: The effect of temperature, substrate, salinity and nitrate, Sci. Total Environ., 635, 1025-1035.

Yang, Y. Y., N. N. Li, W. Wang, B. X. Li, S. G. Xie, and Y. Liu (2017b), Vertical profiles of sediment methanogenic potential and communities in two plateau freshwater lakes, Biogeosciences 14, 341-351.

Zhang, L., L. Wang, K. D. Yin, Y. Lü, D. R. Zhang, Y. Q. Yang, and X. P. Huang (2013), Pore water nutrient characteristics and the fluxes across the sediment in the Pearl River estuary and adjacent waters, China, Estuar. Coast. Shelf S., 133, 182-192.

Zhou, X. P., N. W. Chen, Z. H. Yan, and S. W. Duan (2016), Warming increases nutrient mobilization and gaseous nitrogen removal from sediments across cascade reservoirs, Environ. Poll., 219, 490-500. http://dx.doi.org/10.1016/j.envpol.2016.05.060

Zhu, R. B., Y. S. Liu, H. Xu, T. Huang, J. J. Sun, E. D. Ma, and L. G. Sun (2010), Carbon dioxide and methane fluxes in the littoral zones of two lakes, East Antarctica, Atmos. Environ., 44, 304-311. 
Table 1. Pearson correlation analysis between porewater $\mathrm{CH}_{4}$ concentration and environmental parameters from the shrimp ponds in the Min River Estuary (MRE) and Jiulong River Estuary (JRE) a .

\begin{tabular}{llllllll}
\hline \multirow{2}{*}{ Data set } & \multicolumn{2}{l}{ Porewater parameters } & \multicolumn{3}{l}{ Sediment parameters } \\
\cline { 2 - 8 } & Salinity & TOC & DOC & DIC & Temperature & pH value & TC \\
\hline MRE & NS & $0.775^{* *}$ & $0.596^{* *}$ & $0.558^{* *}$ & $0.714^{* *}$ & NS & NS \\
JRE & NS & $0.744^{* *}$ & $0.433^{*}$ & $0.696^{* *}$ & $0.402^{*}$ & NS & NS \\
All data & $-0.731^{* *}$ & $0.643^{* *}$ & $0.631^{* *}$ & NS & NS & $0.527 * *$ & $0.654^{* *}$ \\
\hline
\end{tabular}

a MRE, Min River Estuary; JRE, Jiulong River Estuary. All data in the table represent all estuaries. NS means "not significant". The symbols * and ** indicate significant correlations at the 0.05 and 0.01 levels, respectively. $n=27$ for environmental parameters, and porewater $\mathrm{CH}_{4}$ concentration from the shrimp ponds in each estuary. 
Table 2. Pearson correlation analysis between sediment properties, porewater $\mathrm{CH}_{4}$ concentration and $\mathrm{CH}_{4}$ release fluxes across the Sediment-water interface from the shrimp ponds in the Min River Estuary (MRE) and Jiulong River Estuary (JRE) ${ }^{\text {a }}$.

\begin{tabular}{llllllll}
\hline & \multicolumn{2}{l}{ Sediment properties } & & & \multicolumn{2}{l}{ Porewater } \\
\cline { 2 - 7 } & Temperature & $\mathbf{p H}$ & Porosity & TC & C/N ratio & Salinity & CH4 concentration \\
\hline MRE & $0.473^{*}$ & NS & $0.469^{*}$ & $0.811^{* *}$ & $0.752^{* *}$ & $-0.649 * *$ & $0.372^{*}$ \\
JRE & $0.443^{*}$ & NS & NS & $0.520^{* *}$ & $0.595^{* *}$ & NS & $0.283^{*}$ \\
All data & NS & $0.366^{* *}$ & NS & $0.859^{* *}$ & $0.854^{* *}$ & $-0.604^{* *}$ & $0.676^{* *}$ \\
\hline
\end{tabular}

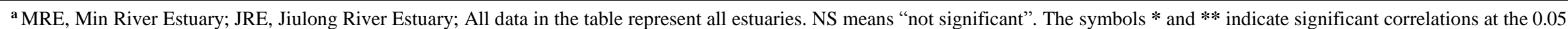
and 0.01 levels, respectively. $n=27$ for sediment parameters, $\mathrm{CH}_{4}$ production rate, porewater $\mathrm{CH}_{4}$ concentration and $\mathrm{CH}_{4}$ fluxes from the shrimp ponds in each estuary. 


\section{Figure captions}

Figure 1. Location of the study area and sampling sites in the Min River Estuary and Jiulong River Estuary, Southeast China.

Figure 2. Dynamics variation of sediment porewater $\mathrm{CH}_{4}$ concentration in the shrimp ponds in the Min River Estuary (MRE) and Jiulong River Estuary (JRE). The boxes, center line, and whiskers represent the $25^{\text {th }}-75^{\text {th }}$ percentiles, median value, and $5^{\text {th }}$ and $95^{\text {th }}$ percentiles, respectively. The square represents the area-weighted average ( $n$ $=9)$. Lowercase letters indicate significant differences $(p<0.05)$ in mean value among growth stages on the same sampling estuary, while uppercase letters indicate significant differences $(p<0.05)$ in mean value among estuaries on the same sampling stage.

Figure 3. Vertical variation of water $\mathrm{CH}_{4}$ concentration and saturation in the shrimp ponds in the Min River Estuary (MRE) and Jiulong River Estuary (JRE). Bars represent mean \pm SE $(n=36)$. The various lowercase letters on the bars indicate significant differences $(p<0.05)$ among sampling depths within each aquaculture stage.

Figure 4. Dynamics variation of (a) $\mathrm{CH}_{4}$ release fluxes across the sediment-water interface (SWI), and (b) overlying water $\mathrm{CH}_{4}$ oxidation rate from the shrimp ponds in the Min River Estuary (MRE) and Jiulong River Estuary (JRE). The boxes, center line, and whiskers represent the $25^{\text {th }}-75^{\text {th }}$ percentiles, median value, and $5^{\text {th }}$ and $95^{\text {th }}$ percentiles, respectively. The square represents the area-weighted average $(n=9)$. Lowercase letters indicate significant differences $(p<0.05)$ in mean value among growth stages on the same sampling estuary, whereas uppercase letters indicate significant differences $(p<0.05)$ in mean value among estuaries on the same sampling stage.

Figure 5. Relationship between (a) water salinity, (b) atmospheric pressure and water column $\mathrm{CH}_{4}$ concentration from the shrimp ponds in the Min River Estuary (MRE) and Jiulong River Estuary (JRE). All data in the figure represent all estuaries. Values of $\mathrm{CH}_{4}$ concentration were calculated as the means of three depths and four sampling times at the same aquaculture stage. Circles + Bars represent mean $\pm \mathrm{SE}(n=12)$.

Figure 6. Relationship between (a) water $\mathrm{CH}_{4}$ concentration, (b) DO concentration and overlying water $\mathrm{CH}_{4}$ oxidation rate from shrimp ponds in the Min River Estuary (MRE) and Jiulong River Estuary (JRE). All data in the figure represent all estuaries. 


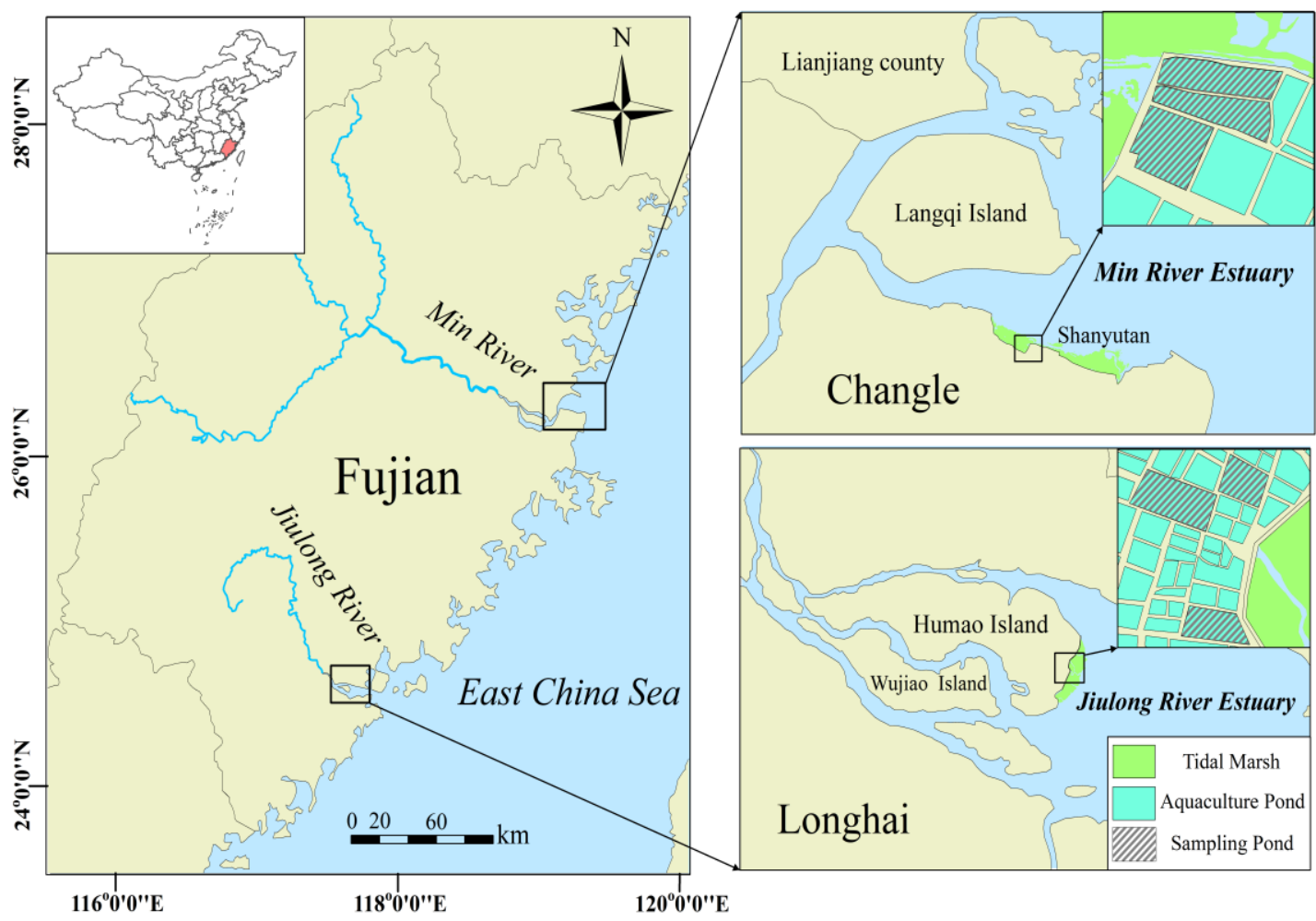

Fig. 1 


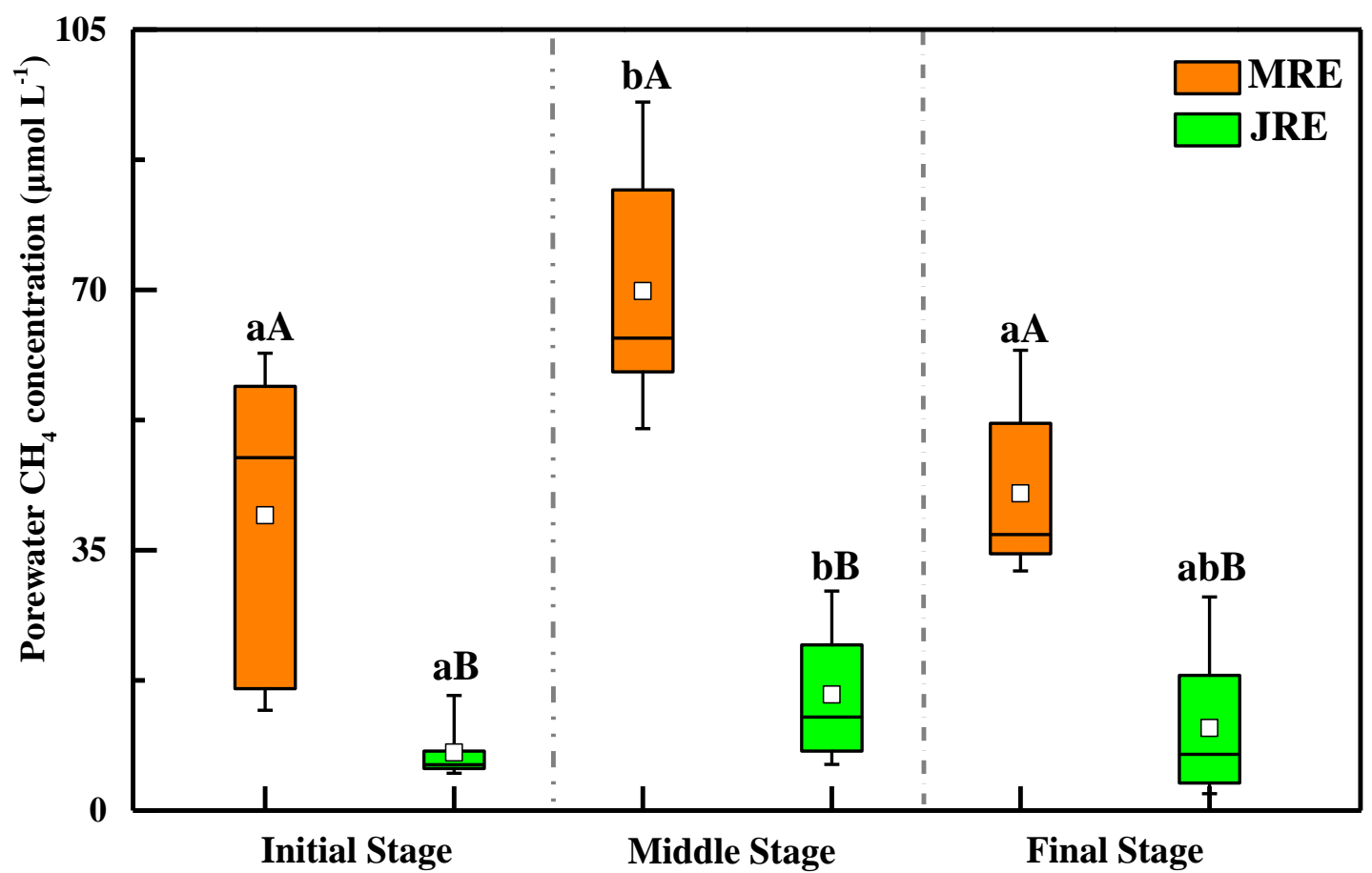

Fig. 2 

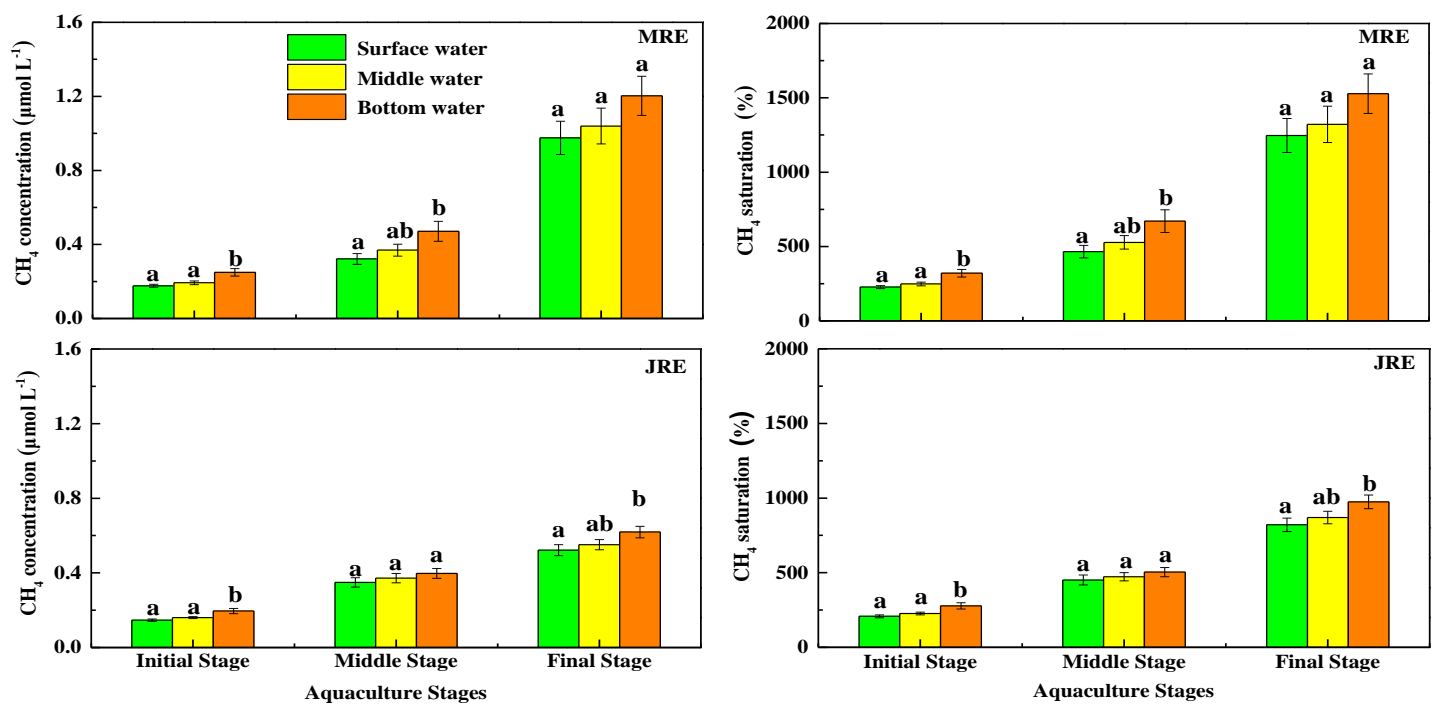

Fig. 3 

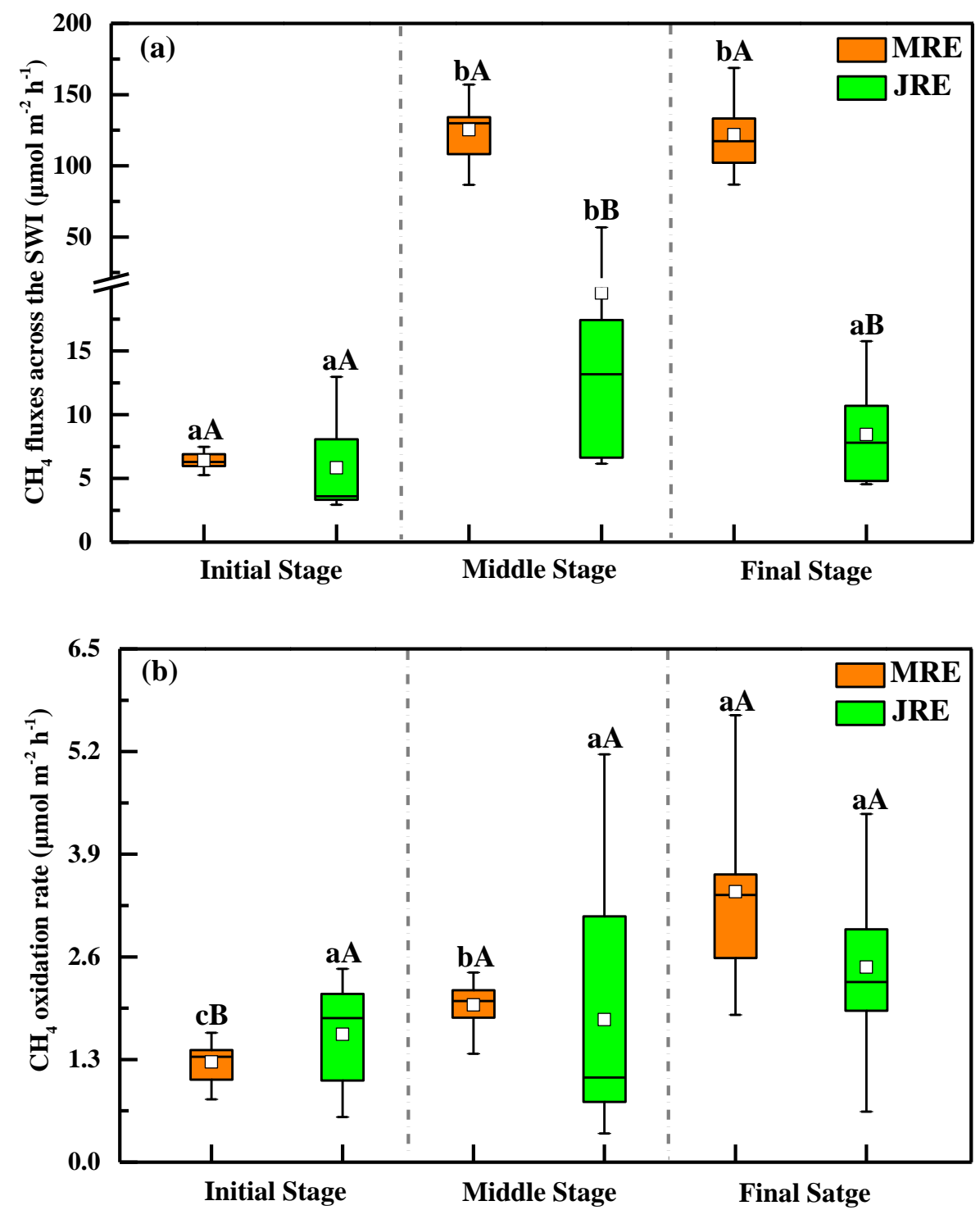

Fig. 4 

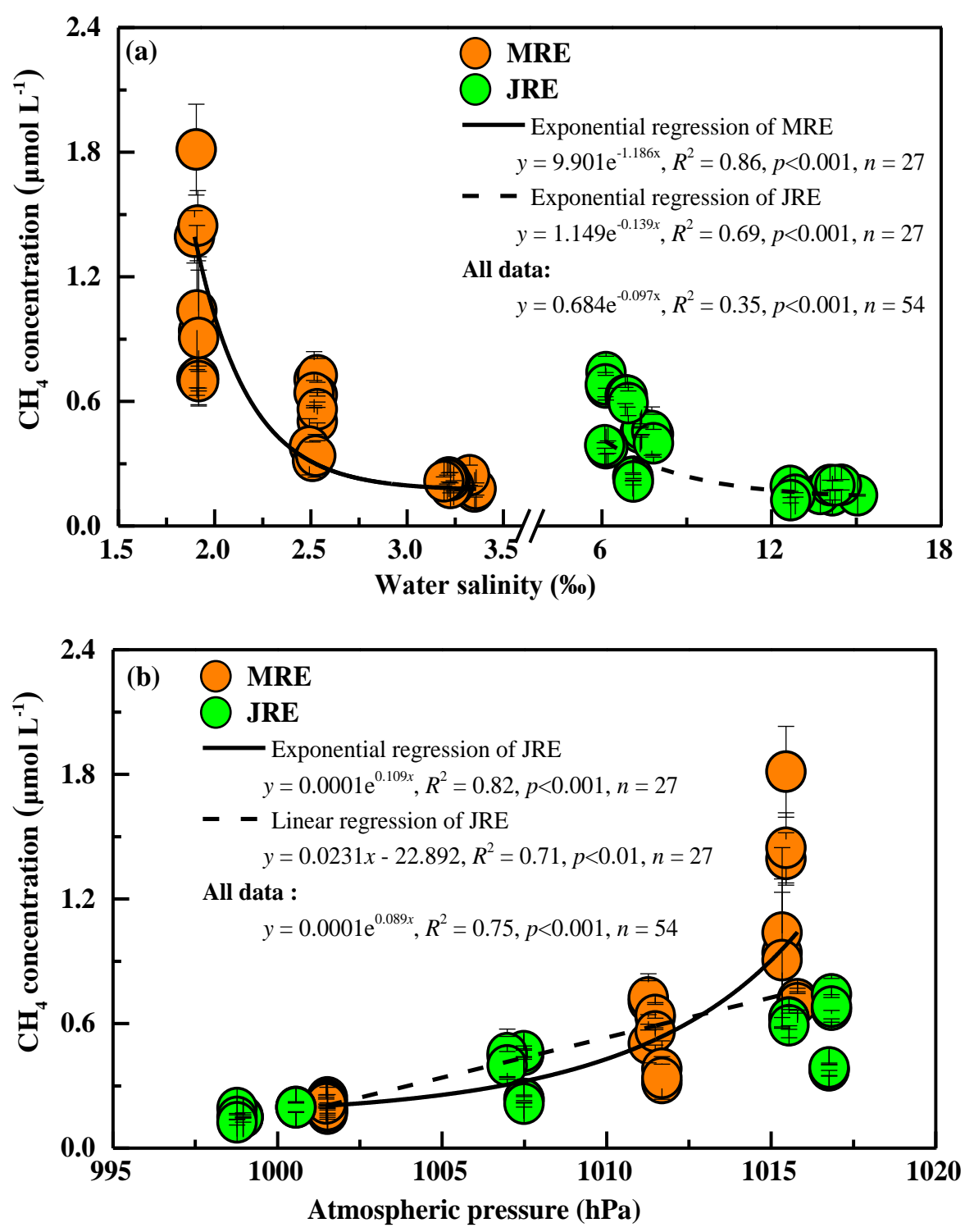

Fig.5. 

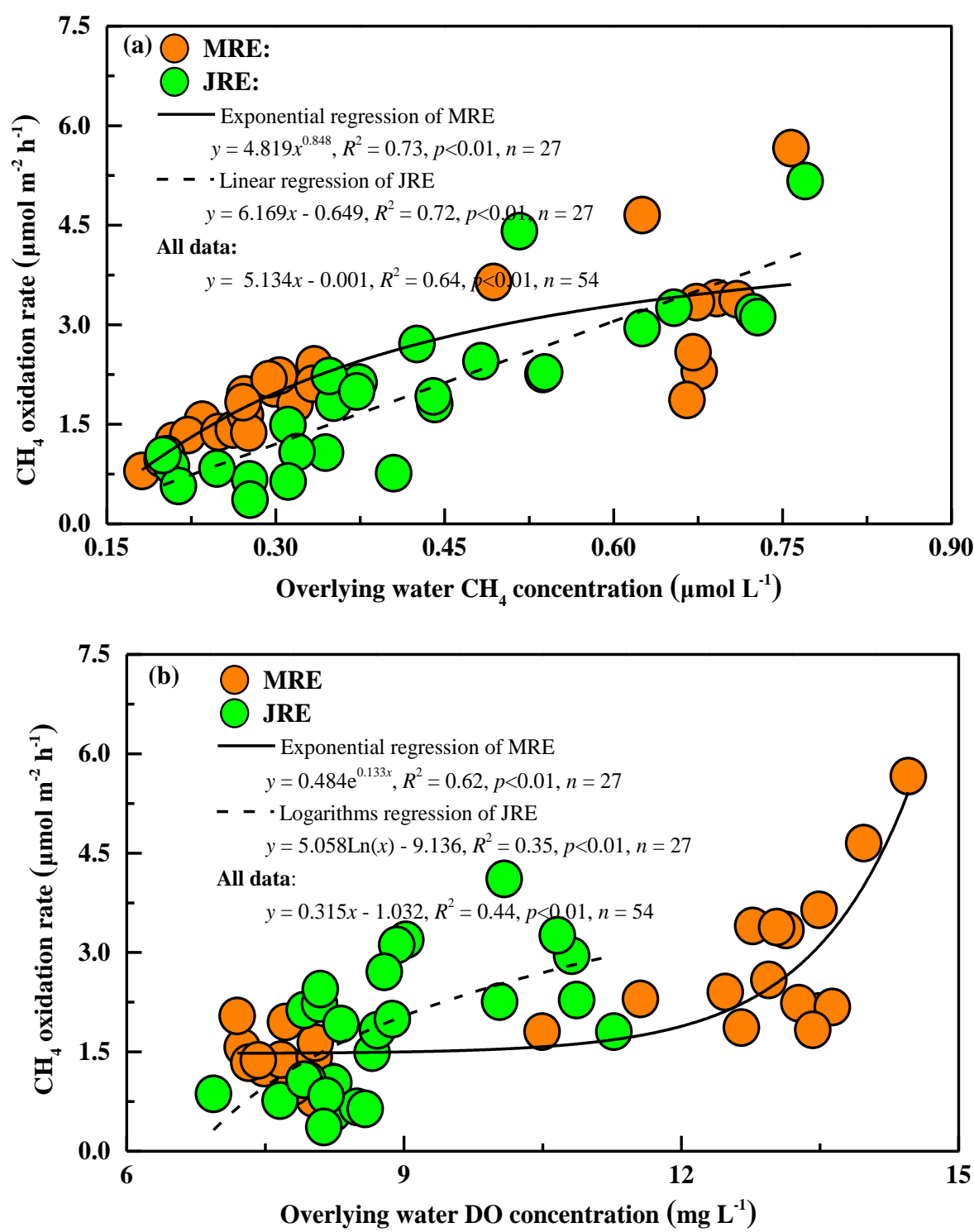

Fig. 6 